\title{
Science Consultants, Fictional Films, and Scientific Practice
}

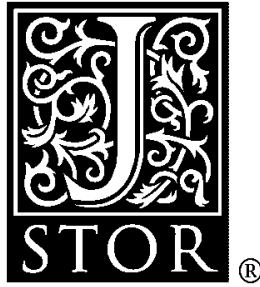

\author{
David A. Kirby
}

Social Studies of Science, Vol. 33, No. 2. (Apr., 2003), pp. 231-268.

Stable URL:

http://links.jstor.org/sici?sici=0306-3127\%28200304\%2933\%3A2\%3C231\%3ASCFFAS\%3E2.0.CO\%3B2-8

Social Studies of Science is currently published by Sage Publications, Ltd..

Your use of the JSTOR archive indicates your acceptance of JSTOR's Terms and Conditions of Use, available at

http://www.jstor.org/about/terms.html. JSTOR's Terms and Conditions of Use provides, in part, that unless you have obtained prior permission, you may not download an entire issue of a journal or multiple copies of articles, and you may use content in the JSTOR archive only for your personal, non-commercial use.

Please contact the publisher regarding any further use of this work. Publisher contact information may be obtained at http://www.jstor.org/journals/sageltd.html.

Each copy of any part of a JSTOR transmission must contain the same copyright notice that appears on the screen or printed page of such transmission.

The JSTOR Archive is a trusted digital repository providing for long-term preservation and access to leading academic journals and scholarly literature from around the world. The Archive is supported by libraries, scholarly societies, publishers, and foundations. It is an initiative of JSTOR, a not-for-profit organization with a mission to help the scholarly community take advantage of advances in technology. For more information regarding JSTOR, please contact support@jstor.org. 


\section{SSSS}

ABSTRACT When scientists act as consultants during the production of a fictional film, it becomes an act of communication that plays a role in the process of science. Fictional film provides a space for scientists to visually model their conceptions of nature. Film impacts scientific practice as science consultants utilize film as a virtual witnessing technology to gather allies among specialists and non-specialists. Film not only has the ability to act as a virtual witnessing technology, but also forces consensus on the public version of scientific debates by presenting a single vision of nature in a perceptually realistic structure. This paper shows films to be successful communicative devices within the scientific community by showing that, and how, other scientists respond to the depictions in the films. It also demonstrates that science consultants use fictional films as promotional devices for their research fields.

Keywords fictional media, perceptual realism, representation, science communication, science consultants, scientific controversy, virtual witnessing

\section{Science Consultants, Fictional Films, and Scientific Practice}

\section{David A. Kirby}

The last 20 years of research in the sociology of science have convincingly revealed the social component in the production of scientific knowledge. One outcome of this research is the understanding that the influences on scientific epistemology are not confined to what scientists 'see under their microscopes'. Analysts of scientific practice have identified various heterogeneous elements that contribute to the creation of scientific knowledge, including instrumentation, technical discourse, social relations, and visual displays used in scientific publications. Cultural studies of science extend these sociological analyses to show a destabilization of the boundaries between activities that constitute science's 'inside' and 'outside'. Media scholars have picked up on this line of research and have begun to ask questions about the impact of mass media on the process of science itself. ${ }^{1}$ While these studies have been incredibly useful in demonstrating the epistemological impact of mass media on science, they have held to a very narrow conception of 'mass media'; primarily news media. But 'mass media' encompasses many more formats, including novels, fictional films, video games, television programs, radio dramas, and comic books. Entertainment media, in particular, are pervasive in society, and yet few analyses exist of entertainment media's effects on scientific practice. These studies are also incomplete because they focus exclusively on documentaries and 
other non-fictional presentations of 'popular' science. ${ }^{2}$ Absent from all of these works on mass media and science is an investigation of fictional media's role in scientific practice. ${ }^{3}$

Reasons for the lack of research on fictional media's impact on scientific epistemology are unclear. It would not be surprising to media scholars that fictional media can have an impact on scientific epistemology, especially since those who focus on visually oriented popular culture, such as fictional films and television shows, have established the impact of fictional media on other areas of epistemology. ${ }^{4}$ Social studies of science have shown that science as a knowledge-producing activity should not be exempt from influences that have been shown to impact other areas of knowledge production. Likewise, it should be evident that fictional media can have an impact on science, given that previous studies of scientific activity reveal the powerful role images and representation have played in scientific practice. ${ }^{5}$ For example, Michael Lynch (1990) illustrates the power of images in his study of visual displays and 'mathematization' in technical publications, especially with regard to images transformed into diagrams or models. Lynch (1990: 154) reminds us to 'recall that visual documents are used at all stages of scientific research'. Historians of science have also called attention to the persuasive capability of images and their role in the construction of scientific facts. Michael Dennis (1989), for instance, discusses the use of images for science communication in Robert Hooke's Micrographia (1665). Dennis (1989: 337, original emphasis) argues that for Hooke scientific representation 'worked as an interpretive method through the claim that there was no processing of the object, only a re-presentation [sic] of the thing itself'. Ultimately, what these sociological and historical works illustrate is that all scientific representations are considered 're-presentations' of nature that provide rhetorical power for scientific claims, and thus, representation plays a significant role in the construction of scientific facts.

Given the importance of representation in science, it should not surprise scholars of science and technology studies that highly visual and rhetorically persuasive media, such as fictional films and television, can be a factor in scientific epistemology. This potential impact becomes more apparent when we take into account additional elements that increase visually based media's capability to 're-present' nature and enhance their rhetorical power, including an aural component, highly advanced representational technologies (i.e. special effects), a complex system of signification, and a narrative framework designed to highlight the representation's 'reality' and to make opaque its construction. ${ }^{6}$ These additional components are especially strong in fictional media. The goal of this essay, then, is to explore the ways in which fictional media impact scientific practice.

\section{Science Consultants for Fictional Films}

To uncover fictional media's impact on science I will examine those situations where fictional media producers consulted with scientific experts 
on the construction of fictional texts, and the reception of these texts by both specialist and non-specialist audiences. This approach is useful because it not only addresses audience reception, but it provides insight into the production of the texts. As studies of scientific representation illustrate, analyses of both reception and production are essential to understand fully the impact of representation on scientific practice. In addition, by concentrating on science consultants I can map the impact of the consulting process on individual scientists and their own scientific work. Fictional entertainment media, however, includes too many formats to make for an effective study of science consultants and fictional media's impact on scientific practice. Therefore, I restricted the scope of the research to science consultants in the production of popular fictional films. Fictional film was chosen over other media forms because it provided the following benefits:

(1) Extensive history as a fictional media form. The cinema was a wellestablished medium before 1900, and it presents over 100 years of cultural records that reveal how the collaboration between scientists and film-makers affects science.

(2) Major Hollywood films reach large audiences over a long period of time. Factoring in theatrical runs, in-flight airplane screenings, cable television showings, pay-per-view, and video distribution, even commercial 'flops' can have a viewership larger than the average television program or novel.

(3) Unlike most television serials, films are singular constructs, making it easier to uncover the relationships involved in their production.

(4) Films have had attention paid to them by the scientific community. Any fictional film which has substantial scientific content, especially those which have had science consultants involved, is likely to be reviewed in major scientific journals (e.g. Nature and Science) and to be the subject of a 'The Real Science of' analysis in books, magazines, and newspapers. ${ }^{7}$

Films and science consultants included in this study were identified by the following method. Plot searches were conducted using film encyclopedias, catalogs, and databases, to ascertain any instances where science was included in plot summaries. ${ }^{8}$ The presence of a 'science consultant' was determined by searching a film's credits. ${ }^{9}$ In many cases, science consultants were listed in the credits only as 'technical advisors'. In these instances, a film's production material was checked to insure that the consultant in question was actually responsible for 'science content'. ${ }^{10}$ Science consultants not listed in the credits of a film were identified through other sources, including newspaper and magazine articles. The interest of this study is in the formation of scientific knowledge regarding the non-human physical world. Therefore, only science consultants from the natural and physical sciences were considered for inclusion. Sociologists, physicians, psychiatrists, and anthropologists were excluded. Ambiguity arose in some cases, and when there was doubt I erred on the side of 
inclusiveness. Using this method I identified 101 films that utilized science consultants spanning a time range of 1914 to 2001 . While this is probably not a complete list of fictional films with science consultants, the films identified provide a wide enough variety over a large enough time span to make for a sufficient analysis of fictional film's impact on scientific practice.

\section{Analytical Framework}

The analytical foundation for this paper comes from science studies research that has demonstrated the importance of scientific representation in the public 'witnessing' of scientific phenomena. Essentially, I maintain that fictional films serve as 'virtual witnessing technologies' that depict natural phenomena in such a way as to convince the audience that the representations accurately reflect the 'natural world'. One of the central questions of scientific epistemological inquiry is, how do scientific interpretations of the natural world become established as 'scientific facts'? For Bruno Latour (1987), a scientific concept becomes a scientific fact, in his terms a 'black box', when the concept has a significant enough number of 'allies' who find the concept 'useful' and/or are convinced that the concept represents an accurate portrayal of nature. Latour maintains that 'science in action' is the process by which scientists gather 'allies' for their framing of natural phenomena. Although some sociologists of science have criticized Latour's model for portraying science as a 'Machiavellian' game (e.g. Shapin, 1988), it is nonetheless a useful framework for examining scientists' actions in the domain of media representation and science communication.

Latour $(1986,1990)$ has argued that representations play a significant role in this process of 'ally gathering' and believes that the rhetorical power of visual representations lies in their mobility. Latour refers to scientific images as 'immutable mobiles' that can be transported from their place of origin and remain 'unchanged', giving them tremendous persuasive capability. These immutable mobiles gather allies for a concept by allowing those who cannot be present to 'witness' the phenomena themselves. Latour (1990: 26-7) claims that immutable mobiles permit scientists to 'present absent things' that are 'presentable all at once to those you want to convince and who did not go there'. Steven Shapin and Simon Schaffer (1985) first put forth this notion of indirect 'witnessing' in their seminal work Leviathan and the Air-Pump. According to Shapin and Schaffer, Boyle believed that the establishment of 'matters of fact' rested upon the premise that all members of the scientific community were able to witness the experiments in which the 'matters of fact' were generated. Of course, it would have been impossible for every member of the scientific community to witness Boyle's experiments directly. Therefore, according to Shapin and Schaffer, Boyle employed the 'literary technology' of 'virtually witnessing' to convince others who were not present of the validity of the 'matters of fact'. As they defined it, 'the technology of virtual witnessing involves 
the production in a reader's [sic] mind of such an image of an experimental scene as obviates the necessity for either direct witness or replication' (Shapin \& Schaffer, 1985: 60, original emphasis). The aim of Boyle's lengthy experimental descriptions and engravings was to convince other scientific investigators of the validity of his experiments without the need for them to have actually 'witnessed' the experiments with their own eyes.

While Shapin and Schaffer centered on the establishment of virtual witnessing as a literary technology in 17th-century Europe their work establishes the significance of 'witnessing', either directly or virtually, to the validation of scientific facts. Shapin (1984: 508, original emphasis) points out that witnessing could be extended outside of a limited number of scientific scholars saying that 'what Boyle was proposing, and what the Royal Society was endorsing, was a crucially important move towards [sic] the public constitution and validation of knowledge'. In his discussion of Michael Faraday's use of the public theater, David Gooding (1989) elaborates upon the crucial role of public witnessing in the formation of scientific facts. Gooding (1989: 202), who cites Shapin and Schaffer, argues that 'demonstration - the witnessing of a phenomenon - is essential to its acceptance into the body of natural knowledge'. The validation of scientific facts no longer rested only in the hands of investigators; access to scientific demonstrations allowed the public to verify 'facts' for themselves. Essentially, Gooding, and other historians of science such as Larry Stewart (1992) and Iwan Morus (1988), are recording the 'move towards the public'. Gooding's historic narrative focuses on the use of public demonstration as a means of 'gathering allies' for particular scientific accounts. $\mathrm{He}$ highlights the significance of seeing in the production of scientific knowledge. No matter how long and descriptive Boyle or Faraday's writings, they still depended heavily on representations.

Even with roving lecturers holding public demonstrations, however, the number of people who can 'directly' witness an experiment or phenomenon is limited. The full 'move towards the public' comes with massmediated technologies, especially visual technologies, which allow for enormous numbers of individuals to visually 'witness' scientific phenomena. Audiences that view scientific phenomena through the visual mass media, like television or film, are not 'directly' witnessing these phenomena, but rather are 'virtually' witnessing them. This expansion of the definition of virtual witnessing is in line with other historians and sociologists who appropriated Shapin and Schaffer's concept, and broadened its definition to include any attempts to persuade others that they have witnessed a 'natural' phenomenon without the need for them to actually witness the phenomenon directly. ${ }^{11}$ It is in this expansive definition that I place fictional film, and other forms of visual mass media, as a virtual witnessing technology. In effect, I consider fictional films' virtual witnessing technologies because they allow large sections of the public to 'witness' phenomena without the need to directly witness these 'natural' phenomena. 
In fact, fictional cinema is particularly useful as a virtual witnessing technology because the intent of its construction is to blur the distinction between virtual witnessing and direct witnessing. This blurring is especially evident for natural phenomena that have never actually been directly witnessed (e.g. dinosaurs). Film scholar Joel Black highlights fictional film's ability to make people believe they have witnessed 'reality', saying:

We need to recognize film as being first and foremost a 'literalist medium' whose nature is to make things explicit [sic] - to reveal or display the world in an evidentiary sense that is beyond the capability of traditional representational or art media. (2002: 8, original emphasis)

Hugh Crawford (1997a: 60) discusses the ability of films to 'display the world in an evidentiary sense' in his study of William Dieterle's film biographies of scientists, saying 'film is ideally suited to reproduce highly dramatized events, to warrant their having actually occurred, and to mark the relative absence/presence of objective knowledge'. Crawford (1997a: 59) claims that Dieterle's bio-pics serve as 'pedagogical tools' that teach audiences how to 'see scientifically'. Since audiences have been 'taught' by the film how to see scientifically, they can 'participate in the validation of the facts being produced' during Pasteur and Ehrlich's public demonstrations in The Story of Louis Pasteur (1936) and Dr. Ehrlich's Magic Bullet (1940) (Crawford, 1997a: 60). Ultimately, Crawford is arguing that the 'public demonstrations' in the film are not limited to convincing the 'audience' in the diegesis, but because they 'display the world in an evidentiary sense' they become public demonstrations for the film's audiences who have also 'witnessed' the experimental scenes. Film, then, can work as a powerful virtual witnessing technology because of this evidentiary element.

Scientists can take advantage of this virtual witnessing technology to 'gather allies' for their scientific concepts by consulting on fictional films. This is not to say that scientists consult with film-makers specifically to utilize film's capabilities as a virtual witnessing technology. Most scientists view consulting on fiction as an activity unrelated to the process of science. Nonetheless, scientists accrue the benefits of film as a virtual witnessing technology, even though they may have chosen to consult for reasons other than 'gathering allies'.

\section{Fictional Representation, Disputed Science, and Perceptual Reality}

I must note two things before proceeding. First, the analytical framework of gathering allies refers only to representations in fictional films of science for which there is not a consensus within the scientific community (i.e. not black boxed). For example, the 1978 film The Boys From Brazil portrayed scientific concepts not entirely accepted by the scientific community. Developmental biologist Derek Bromhall from Oxford University served as the sole science consultant, and filmmakers asked Bromhall to consult based on the publicity surrounding his research on nuclear transplantation in rabbits (Bromhall, 1975). Bromhall's responsibility was to construct an 
explanation of mammalian cloning that could be used in a scene in which cloning is explained to the Nazi hunter Ezra Lieberman by Professor Bruckner. The film presents Bruckner's discussion of mammalian cloning in a very straightforward manner as if anyone who wanted to achieve mammalian cloning would follow the protocol given in the movie. In the late 1970 s, the developmental community debated the procedure of mammalian cloning; the description given in the film's narrative is fundamentally the version that was advocated by Bromhall during this time. ${ }^{12}$ The scientific community had not yet settled on the mechanism to transplant the nucleus from the donor cell to the recipient cell, and discussion centered on cell-cell fusion, Bromhall's technique, versus nuclear microinjection. In addition, biologists disagreed over the use of eggs as recipient cells, which Bromhall preferred, as opposed to the use of fertilized zygotic cells. Even the question of what animal (rabbit or mouse) would best serve as a vehicle for mammalian cloning was in debate. The film, of course, does not imply uncertainty about any of these topics and presents Bromhall's conception of mammalian cloning as the only available model.

Second, films can act as virtual witnessing technologies despite their fictional nature, because while the images on the screen are fictional they appear to be 'real'. Film theorists have recently grappled with the idea of 'realism' in regard to special effects and are now revising old theoretical models to accommodate the rise of computer-aided digital imaging. ${ }^{13}$ Film theorist Julia Hallam (2000) reviewed theoretical work on filmic reality in her 2000 book Realism and Popular Cinema. According to Hallam, the rise of the blockbuster 'spectacle' film in the 1980s and 90s has resulted in a renewed emphasis on film 'realism'. She argues that rather than being 'unrealistic', films that heavily rely on special effects actually embody realist film-making, in that they must make 'unreal' images actually appear 'real'. In order to maintain the interest of audiences, these films must 'be sufficiently credible to be possible in terms of what constitutes a rational possibility of the unknown' (Hallam, 2000: 78). As stated by Noel Carroll (1996), contemporary film theorists now 'agree that in its standard uses, film imparts a realistic effect [sic] to its viewers' ${ }^{14}$ Joel Black (2002) refers to film's ability to 'mimic' reality as the 'reality effect'. Black (2002: 7) believes that the reality effect is disturbing because it has made film 'a key role in determining "reality" itself'.

Stephen Prince (1996a) has effectively argued that the key to understanding the reality effect is not to consider filmic images as conforming to referential reality but, rather, that they are perceptually realistic. ${ }^{15}$ Prince (1996a) uses correspondence theory to describe how images can be referentially unreal, but perceptually realistic:

A perceptually realistic image is one which structurally corresponds to the viewer's audiovisual experience of three-dimensional space. Perceptually realistic images correspond to this experience because film-makers build them so. Such images display a nested hierarchy of cues which organize the display of light, color, texture, movement, and sound in ways that correspond with the viewer's own understanding of these phenomena in 
daily life. Perceptual realism, therefore, designates a relationship between the image or film and the spectator, and it encompasses both unreal images and those which are referentially realistic. Because of this, unreal images may be referentially fictional but perceptually realistic. ${ }^{16}$

In other words, film-makers design images, even unreal images, to correspond to 'cues' with which viewers normally interact. Familiarity with these cues compels the audience to perceive unreal images as realistic. Prince (1993) uses Furassic Park as an example of how film-makers create perceptually realistic images using digital technology:

No one has seen a living dinosaur. Even paleontologists can only hazard guesses about how such creatures might have moved and how swiftly. Yet the dinosaurs created at ILM [Industrial Light and Magic] have a palpable reality about them, and this is due to the extremely detailed texture mapping, motion animation, and integration with live action carried out via digital imaging. Indexicality cannot furnish us with the basis for understanding this apparent photographic realism, but a correspondence-based approach can. Because the computer generated images have been rendered with such attention to $3 \mathrm{D}$ spatial information, they acquire a very powerful perceptual realism, despite the obvious ontological problems in calling them 'realistic'. These are falsified correspondences, yet because the perceptual information they contain is valid, the dinosaurs acquire a remarkable degree of photographic realism. (Prince, 1996a: 34)

Because of the accuracy of digital technology, we see unreal animals (e.g. dinosaurs) that match the movement, appearance and sounds of animals with which we have interacted. Therefore, we perceive these images as realistic, even though they are not actually real. This perception actually enhances film's persuasiveness and its ability to act as a virtual witnessing technology.

Communication researchers have also addressed the issue of the perceived reality of entertainment media in terms of audience reception. According to Michael Shapiro and Makana Chock (1999) there are two ways of considering perceptual reality. 'Absolute' perceptual reality is the degree of perceived similarity between mediated images and situations and real life objects and situations. 'Relative' perceptual reality is more appropriate for considering the depiction of science in fictional media because it involves judgments about how 'real' images and situations are if those sorts of images were to actually exist or those situations were to actually occur. The work of Martin Barker and Kate Brooks (1998, 1999) on audience reception of the film fudge Dredd (1995) supports the notion of relative perceptual reality. They interviewed film-goers about their perceptions of the future world depicted in the film and found that audiences make judgments about what is 'plausible' within the film's diegesis, not necessarily what is 'real'. That plausibility leads to the perception of reality is important, because, as paleontologist Kevin Padian (1987) has shown, the role of popular images in the acceptance of scientific concepts depends not on their correspondence to 'reality', but rather on their plausibility. ${ }^{17}$ 
According to Padian, pictorial representation is a 'powerful determinant of perception' that 'need only be plausible, not accurate, to become fixed in the mind's eye'. In his study of the taxonomic reconstructions of pterosaurs, Padian found that popular images supplanted even scientific evidence in scientific reconstructions, saying that 'the popular reconstruction of pterosaurs assumed an important role in establishing the acceptance of the bat-winged image, in spite of the lack of evidence then or now for it'. In the end, Padian concludes that 'a picture is not only worth a thousand words; however inaccurate, it may be worth a wealth of documented evidence to the contrary'.

Although the development of digital imaging created and increased attention to 'realism' among film theorists and communication researchers, the ability of film-makers to create perceptually realistic images preceded this technology. As Prince (1996a: 34) points out, 'The tension between perceptual realism and referential artifice clearly predates digital imaging'. There are several instances where viewers were unable to distinguish whether images on the screen were special effects or were real. For example, the special effects for The Lost World (1925) were so convincing that many people believed that Arthur Conan Doyle had actually filmed 'real' dinosaurs. Doyle showed a test reel of the dinosaurs to the Society of American Magicians and, 'the motion pictures were presented without titles or comment of any kind, and the audience was left strictly to its own conclusions' (Anonymous, 1922a: 4). A bewildered New York Times reporter exclaimed, 'His monsters of the ancient world or of the new world which he discovered in the ether, were extraordinarily lifelike. If fakes, they were masterpieces' (Anonymous, 1922a). Doyle's subsequent revelation that the reel was to be part of The Lost World apparently embarrassed the reporter, who wrote a follow-up report the next day clarifying that the dinosaurs were fakes (Anonymous, 1922b). Whereas The Lost World demonstrates how audiences may confuse special effects with real objects, the reverse situation also occurs. A scene in the film Contact (1997) depicts fictional astronomer Ellie Arroway sitting in front of a collection of large radio telescopes. The radio telescopes in the film actually exist and Warner Brothers filmed the scene on site in New Mexico. According to astrophysicist Philip Plait (1997), when the scene first appeared on the screen the person in front of him thought the image was computer-generated, uttering to his companion, 'What a great effect!'. Plait's response to this confusion between reality and effect was, 'How cool is it that we astronomers have instruments so impressive that people think they aren't real?' What this actually demonstrates is that film images have become so perceptually realistic that audiences are unable to determine whether filmic images are 'effects' or 'reality'.

'Realism', in fact, is the reason film-makers consult scientists in the first place. A science consultant's job is to make sure that the scientific images are not 'fiction' but that they conform to 'natural reality'. Filmmakers who consult with scientists explicitly state their need for 'reality'- 
based science. For example, Brian De Palma, director of Mission to Mars (2000), claims:

What we've tried to do is to make 'Mission To Mars' as authentic as possible, and it's what we've realized. The film is all the more exciting because you feel like it's extremely real. The various things that happen to the Mars One and Two crews in this film all come out of the physics of what could happen in the situations presented in the story. So, it is realistic and extremely authentic. (quoted in Production Notes, 2000)

Likewise, Van Ling, the computer-graphics supervisor for Banned from the Ranch, used science consultants to achieve 'realism' for the effects in the film Twister (1996). Because he was:

determined to create displays that were as realistic as possible for the few stormchasers and meteorologists who might take the film seriously, Van traveled to the National Severe Storms Laboratory in Norman, Oklahoma, where meteorologists Kevin Kelleher and Philip Bothwell gave him a crash course in the scientific yet intuition-based field. (Banned from the Ranch, 1996)

Science communication researchers Edna Einsiedel and Bruce Thorne (1999) found that previous research in science communication followed one of two models: (1) a scientific literacy model and (2) an interactive science model (see also Logan, 2001). Previous analyses of fictional media and science have used the science literacy model to demonstrate how culture simultaneously influences and shapes public images of science. In this model, 'culture' is a matrix that influences how fictional images are produced and subsequently impacts how the public perceives science and scientists. The goal of research under this model is to understand 'culture' through an analysis of the fictional images. While research on fictional media based on the scientific literacy model has increased our understanding of public perceptions of science, the model does not go far enough. In essence, the scientific literacy model has left out 'science' itself. I propose a move towards the interactive science model for analyzing fictional presentations of science, one that not only incorporates science's impact on fiction but fiction's impact on science. In the interactive science model, 'culture' remains as a matrix that influences how images are produced, but the model takes into account that these images in turn shape science. Using the interactive science model to examine the role of science consultants in the production of fictional films, in conjunction with the analytical framework described above, I will map the impact of fictional films on the process of science. First, I demonstrate how films as virtual witnessing technologies can be used to communicate with non-specialists. Second, I demonstrate how fictional films, like other media forms, play a role in inter-specialist communication. 


\section{Popularization, Fictional Films, and the Non-Specialist Community}

Most scientists view their consulting work on fictional media as a popularizing activity that can help to counteract the overall negative portrayal of science documented in prime-time television shows and in horror films. ${ }^{18}$ For example, Cornell University astronomer Carl Sagan (1995) felt that accurate scientific depictions in the media would facilitate a better public understanding of science. It was this belief that motivated him to make sure that the science in the film adaptation of his novel Contact was portrayed 'correctly' (Davidson, 1999). Likewise, Joshua Colwell from the University of Colorado, who was a 'comet advisor' on the film Deep Impact (1998), cites the need to 'educate' the public about 'real science' as a major reason for consulting: 'Many people's ideas about what is and what is not realistic and possible are formed almost exclusively by popular culture depictions. That's not a good thing' (quoted in Bradley, 2001). Consulting on fictional films as a means of science advocacy is true historically as well. Astronomer Samuel Herrick of the University of California - Los Angeles, for instance, acted as science advisor for The Day the Earth Stood Still (1951) because he felt that space-themed films were 'popularizing and encouraging the work of scientists in this field' (quoted in Twentieth Century Fox, 1951).

In their review of science popularization research, science communication scholars Jane Gregory and Steve Miller (1998: 85) come to the conclusion that 'popularization is essentially an act of persuasion'. As discussed earlier, film as a popularizing activity can be very persuasive because of its ability to act as a virtual witnessing technology. Scientists and film-makers create representations with the purpose of convincing people that what they are seeing on the screen is a 'true' depiction of the way things 'really are', and these representations are embedded in a framework designed to encourage this belief. Several studies over the last 10 years found that the audience for popularization via newspapers and magazines is not limited to the 'lay' public; popularized accounts of science are also meant to persuade other scientists. Nonetheless, it is still important to address how communication with non-specialists can impact the process of science.

\section{Fictional Films and Ally Gathering in the Non-Specialist Community}

Communication researcher Leah Lievrouw (1990: 9) states that science popularization serves several purposes, one of which is a 'process by which a scientific idea gains currency in the everyday discourse of the general public'. David Gooding captures the role of public acceptance in scientific epistemology in his discussion of Michael Faraday's use of the public theater:

People act upon nature to generate new possibilities for observation. However, these remain mere possibilities (and private ones at that) until they are successfully communicated to lay observers, whose witness 
confirms the existence of the phenomena. Witnessing requires a shared means of experiencing the outcomes of interventions, and so discoverers must invent new representations that present the phenomena in a way that novices can be shown what they are to witness. (1989: 191)

As virtual witnessing technologies, fictional films are 'new representations' that science consultants can utilize to 'confirm' the existence of phenomena and disseminate their concepts among the general public.

Again, the 'use' of fictional films as virtual witnessing technologies does not necessitate any intentionality on the part of science consultants. For example, special effects technicians Willis O'Brien and Marcel Delgado consulted with several paleontologists in order to create the dinosaurs in King Kong (1933). In one case they consulted Barnum Brown on the depiction of Tyrannosaurus rex. One area of contention among paleontologists in the 1920s and 30s was the number of digits on T. rex's forelimb. Brown, who was then famous for his reconstruction of $T$. rex for the American Museum of Natural History in New York, vociferously maintained that T. rex had three digits on its forelimb. More than likely, Brown was not thinking about 'gathering allies' when he recommended a threedigit T. rex to the film-makers. However, his insistence on this depiction for T. rex in King Kong guaranteed that millions of people would 'witness' his vision of $T$. rex morphology and, thus, enhanced his opportunities to propagate his version of natural 'reality' (Goldner \& Turner, 1975: 141).

\section{Fictional Film and Promotional Opportunities}

In addition to its ability to help consultants promote their conceptions of nature to lay audiences, the filmic presentation of science to the public can impact science in other ways. Leah Lievrouw (1990: 9) notes that popularization serves not only to convince the public about the validity of scientific information, 'it is also essentially a communication process that facilitates the gathering of resources for pursuing certain lines of research'. Sociologists and historians have often demonstrated that popularization is akin to promotional activities of scientists, especially with regard to obtaining funding or other support for their research. As sociologist Stephen Hilgartner (1990: 531) notes, 'a mountain of evidence shows that experts often simplify science with an eye toward persuading their audience to support their goals: build support for research programs'. This is as true for fictional films as it is for any other form of popularization. In the following subsection, I show how fictional films can impact science by acting as virtual witnessing technologies for non-specialist audiences. Science consultants can use depiction in fictional films to enhance funding opportunities and promote research agendas, and other scientists and science organizations also use fictional films as fundraising tools.

Many consultants perceive fictional films as a way to promote their science in the hope of convincing the public that their scientific field needs and/or deserves more research funding. Often, consultants will proclaim that the film on which they are working highlights an issue that needs more 
'attention', in other words funding, from the American public. NearEarth-Objects (NEO) permeated the scientific and cultural climate in 1997, the year that two asteroid/comet impact films, Deep Impact and Armageddon (1998), went into production. These films provided an opportunity for science consultants, all of whom had a stake in the NEO debate, to promote the hypothetical dangers of NEO. For example, Joshua Colwell's research involves 'small objects' in the solar system such as comets. He hoped that his consulting work on Deep Impact would help inform the public about the dangers of comet impacts:

The more realistically things are portrayed, the better it is for everyone producers and public alike. The basic premise of Deep Impact is scientifiically sound in that life on Earth faces a threat due to comet and asteroid impacts. That threat might be mitigated through observation and destruction or deflection of the object with nuclear bombs. The fact that the movie made an effort to portray all this realistically helps convey this message to the public and raise awareness of a real issue. (Film-maker in Bradley, 2001)

In addition, Carolyn and Eugene Shoemaker, who pioneered the field of astrogeology and who co-discovered Comet Shoemaker-Levy 9, both acted as consultants on the film Deep Impact, and each had a role in the NEO projects of the National Aeronautics and Space Administration (NASA). Likewise, Joseph Allen and Ivan Bekey, who consulted on Armageddon, both consult for the federal government on matters of NEO protection. Astrogeology itself is a relatively new field of study, and scientists in this field are competing with more established areas of research for federal research dollars. Having two films depicting NEO may have been beneficial for the field of astrogeology and the specific consultants.

Many other astronomers were hopeful that the film would bring the NEO issue to the attention of the public and expected that the film would raise awareness, and funds, for NEO research. For example, David Morrison, head of space research at NASA's Ames Research Center, believed that the films could be considered as 'public service announcements': 'It [Deep Impact] may do more to alert the public to the impact hazard than anything in the past. And its images may even keep you up at night wondering if we are doing enough to protect our planet against this threat' (quoted in Chandler, 1998). Morrison also says, in what was a common lament found in interviews with scientists about the films, that he wishes some of Deep Impact's box-office takings could go towards NEO research like Spaceguard, a survey for NEO: 'The first week's gross from "Deep Impact" would be enough to implement the Spaceguard Survey, Morrison noted wistfully. That gross was $\$ 41.9$ million' (quoted in Chandler, 1998). ${ }^{19}$

Many news commentators, in fact, think that the publicity surrounding these two films, and their impact on public opinion, played a major role in the development of a NEO agency in the USA. An editorial in The Denver Rocky Mountain News, for example, claimed that the US NearEarth Object Program Office, founded in June 1998, would not have come 
into existence without the help of these two films and other popular cultural sources:

Sensationalize it, and the government will follow. Thanks to movies like Armageddon and Deep Impact and TV shows like 'Asteroid' and countless lurid magazine covers about asteroids and comets destroying Earth, or at least seriously damaging midtown Manhattan, NASA has set up a special office to track threatening stuff in space. (Anonymous, 1998).

Several scientists who testified before Congress on 21 May 1998, just after the release of Deep Impact, used the film to bolster their claims for a NEO detection and deflection system. ${ }^{20}$ Members of Parliament, such as Lembit Opik, and Britain's Science Minister, Lord Sainsbury of Turville, acknowledge the direct role the two films played in their decisions to lobby for the British National Asteroid and Comet Information Centre (NACIC), and ultimately in their ability to establish the governmental task force. Opik, who led the charge for the task force, directly attributes its passage to the public support garnered by the two films:

It [NACIC] marks a personal victory for the Liberal Democrat MP [Member of Parliament] Lembit Opik, who has waged a lone campaign in the Commons for the issue to be taken seriously. 'I don't think that people are laughing any more at the idea that NEOs are a real threat. Two or three years ago there was a high giggle factor about NEOs but in the last 18 months the scientific community and the general public have changed their view measurably. The popular media has woken up to the threat because of Deep Impact and Armageddon. It is literally a matter of life and death if there is an impact. (Brown, 2000).

Lord Sainsbury also acknowledges the film's importance in establishing the task force and he believes 'public concern at the chances of annihilation have been heightened by recent Hollywood movies such as Deep Impact and Armageddon' (quoted in Brown, 2001). According to one newspaper article, the two films are what prompted scientists to study the risk of impacts:

[scientists'] warnings went unheeded until two recent Hollywood films, Armageddon and Deep Impact, showed Earth being ravaged by such impacts. The publicity prompted scientists at the British National Space Centre (BNSC) to investigate the risk, and their report is said to have startled the government into action. (Leake \& MacAskill, 1999)

The use of fiction to convey the importance of a consultant's research certainly worked for pioneering rocket scientist Hermann Oberth and the German Society for Space Travel (VfR). Fritz Lang hired Oberth to consult on his 1929 motion picture Frau Im Mond [Woman in the Moon]. ${ }^{21}$ Lang wanted to follow-up his science fiction masterpiece Metropolis (1926) by constructing the first 'scientifically accurate' space flight film. Despite his pioneering work on rocketry, Oberth was in desperate need of funding for his research (Ley, 1968). In exchange for working as scientific advisor for the film, Lang promised Oberth that he would receive money out of the 
film's advertising budget, and out of Lang's own pocket, to conduct experiments on his Model B liquid-fuel rocket. In addition to his consulting work, Oberth was expected to build a working rocket to be launched at the film's premiere in October 1929 as a publicity stunt. Oberth envisioned the launching of this rocket at the premiere as a way for him to demonstrate the feasibility of his ideas. Unfortunately, Oberth was not able to produce a working rocket by the time of the film's premiere.

Nonetheless, Oberth and Willy Ley, a founding member of the VfR and also a consultant on Woman in the Moon, saw the promotional possibilities inherent in being in a 'Fritz Lang' film. According to Ley, 'A Fritz Lang film on space travel, consequently, meant a means of spreading the idea [of space travel] which could hardly be surpassed in mass appeal and effectiveness' (Ley, 1968: 115). The lift-off that Oberth designed for the film was able to convey the possibilities of rocket travel to prominent individuals, including Albert Einstein, and potential funders at the film's premiere. According to Ley's account, the take-off of the rocket from Earth caused a roar of emotion from the premiere audience:

There is without question no other scene, either on Earth or on the Moon, that would have ruffled the poise of this cool, reserved, expert audience - these journalists, scholars, diplomats, men of affluence, and film stars. In the face of these outstanding technical achievements, the audience exploded. Electrified, carried away. The fiery jets of this film rocket swept away their carefully prepared skepticism, indifference, and satiety with the same speed with which the rocket raced across the screen, giving their minds a small glimpse of the tremendous possibilities. (quoted in Freeman, 1993)

In a sense, the success of this image on the screen made Oberth's failure to produce a rocket for the premiere irrelevant. The audience walked away thinking they had seen Oberth's rocket, because they saw a rocket take off in the film.

It is fictional film's ability to create an image of 'scientific possibilities' in the audience's mind that leads scientists to believe that 'realistic' depiction can lead to higher funding levels. Joel Black refers to this as the 'War Games effect' after the 1983 film and claims that 'by presenting apocalyptic narratives in the fictional form of movies or thrill rides, specialeffects technicians are ... playing (or banking) on the notion that by presenting these doomsday scenarios in a fictional form, they are preventing [sic] them from happening' (2002: 24, original emphasis). Virologist Peter Jahrling of the US Army Medical Research Institute of Infectious Diseases buys into the 'War Games effect', making the connection between 'realism' in fictional film, public awareness, and increased research funding in a Health magazine article on the film Outbreak (1995):

'If the film [Outbreak] has a ring of truth to it, people will walk out thinking, Jesus, that story may have been fiction, but it could happen, couldn't it? But if it's clearly just science fiction, they'll write it off like the latest Sylvester Stallone movie.' Which would be too bad, says Jahrling, because only a fired up public will favor spending research dollars on 
vaccines and other precautions against an obscure killer virus before [sic] it goes global, not after. (Roach, 1995)

Scientists worry about the image of science in fictional pieces because they perceive that popular cultural portrayal is connected to popular opinion and funding (Kirby, 2000). If 'accurate' portrayal can lead to increased public support for science, then 'inaccurate' portrayal has the possibility of decreasing public support.

Many scientists and science organizations that do not consult have used fictional films as direct promotional devices and fundraising tools because of film's capacity to act as a virtual witnessing technology, to visually show audiences scientific 'possibilities'. Robert Esnault-Pelterie, one of Oberth's scientific rivals, showed the take-off scene from Woman in the Moon at a 1931 fundraising event in New York City (Anonymous, 1931a, 1931b). The New York Times reported, 'Last night's spectators watched it [footage from Woman in the Moon] as if it were a newsreel of an actual happening today' (Anonymous, 1931b). In a similar vein, many scientists and scientific organizations saw publicity value in the film Mission to Mars. Matthew P. Golombek, project scientist for NASA's 1997 Mars Pathfinder mission, acted as a science consultant on the film. He admits that he was unable to convince the film-makers on several points of 'scientific accuracy'. However, 'for Golombek, the exaggerations do not detract from the real value of the film: to convey the sense of adventure in Mars exploration and, just maybe, to galvanize the public' (Yam, 2000). Golombek himself concludes, 'Hollywood does a much better job of talking about what NASA does than NASA does itself' (quoted in Yam, 2000). The Mars Society, an organization dedicated to promoting and studying scientific exploration of Mars, took this notion to heart. During the film's theatrical run, they distributed literature and collected signatures for a petition in theater lobbies around the country (Conklin, 2000). In the same way, The Paleontological Research Institution in Ithaca, New York, set up a display in the lobby of a local theater showing furassic Park III (2001). What all these examples show is that members of the scientific community consider fictional films to be effective promotional tools. When science consultants are involved in the construction of these films they can significantly shape the public face of their research areas and help make the case for more research support.

Overall, what consultants are finding is that popularization through fictional films allows them to communicate their scientific ideas and conceptions to the non-specialist audience. The presentation of science within the cinematic framework can convince the public of the validity of these ideas and foster public excitement about research agendas.

\section{Fictional Films and Inter-Specialist Communication}

Perhaps even more interesting than the effect of fictional films on nonspecialists is the possibility that these films can shape scientific knowledge itself. Sociologists of science have identified informal communication 
activity as a component of the scientific process. For example, sociologist Stephen Hilgartner (1990) contends that scientists use non-technical routes of communication for social and political purposes within the scientific community. Likewise, Massimiano Bucchi (1996: 380) has persuasively argued that the 'active influences of the popular discourse of science cannot be reduced to feedback mechanisms of public support and legitimization'. Bucchi (1996: 386) has documented that accounts in nontechnical media can impact science because they 'can foster the inclusion or exclusion of actors or theories from the specialist's discourse, and it [popular accounts] can make room for new interpretations or confer a different status on existing models by linking them to other public issues and themes'. Other communication scholars have established through the 'interactive science model' that scientific communication through alternative routes is not just a 'sharing' of scientific knowledge with the public, but is a component in the making of that knowledge. Bart Simon (2001: 383) uses the cold fusion case to demonstrate that 'mass media do not just mediate the relationship between experts and lay public; they also mediate the relationships among experts with the strong epistemological force of affecting what goes on in the laboratory'. Bruce Lewenstein $(1995,2001)$ proposes a new science communication model to take into account the impact of non-technical literature on specialist communication. Lewenstein's 'web' model offers an integrated approach to science communication in that technical media and mass media interact in complex ways, informing and referring to each other.

All these efforts show that science communication outside of technical literature can be used as communicative devices within the scientific community, and is not limited to 'disseminating' scientific knowledge to non-specialists. Although these studies are based on news media, other researchers have established that inter-specialist communication occurs through 'documentary' films and television shows as well. ${ }^{22}$ Gail Davies (2000), for example, discusses the collaboration between naturalists, filmmakers, and scientists in the establishment of the Natural History Unit of the British Broadcasting Corporation. She finds that 'early natural history television was not the endpoint for the communication of fully developed scientific discourses on animal behavior, but constituted a set of narratives, values and practices with which both scientists and broadcasters engaged' (Davies, 2000: 433). Science documentaries serve as virtually witnessing technologies, because, like photographs, they appear to be referentially realistic. That is, to the audience the images and activities on the screen are 'referents' to real entities and situations in the natural world.

According to historian of science Gregg Mitman (1999) the purported referential reality or 'authenticity' of nature films was historically important to the scientific community whose nature films allowed the public, and other scientists, to 'witness' nature in action. Scientists embraced nature documentaries as research tools early in cinema history, because they believed that 'the camera offered a close-up, intimate look into the daily 
seasoned life of animals' and that 'the camera offered a wide-angle panoramic vision that revealed the intricate relationships among life' (Mitman, 1999: 58). As Mitman points out, both scientists and film-makers benefited if audiences accepted as true that they were 'virtually' witnessing natural reality in a scientific documentary. Film-makers that could claim 'authenticity' for their films enhanced their ability to draw in audiences. For scientists, the utility of science documentaries as research and educational tools was dependent on the audience's conviction that the films 'mirrored' the reality of the natural world. According to Mitman, need for scientists to defend nature documentaries as being 'authentic' led to scientists vehemently attacking nature films that were obviously employing fakery, such as the exploitation film Ingagi (1930). Despite the scientific community's insistence on the 'authenticity' of nature films, Mitman shows that documentaries were as thoroughly constructed as fictional films. Mitman found that while scientists and film-makers wanted to convince both the public and other scientists that they were showing 'reality' documentaries these were, in fact, substantially edited and dramatized to enhance their entertainment value.

In spite of the highly stylized nature of documentaries, scientists understand non-fictional entertainment media, and news media, to be scientific communication devices, even if they think they are only communicating to the general public. How can fictional films, a medium not usually considered even in terms of lay-communication of science, be relevant to inter-specialist communication? To answer this question, it is important to remember that film is a communication technology. According to communication researcher James Grunig (1980: 185), 'The purpose of communication is to reconstruct one person's idea in another person's mind'. For the most part the 'reconstruction' process is entirely in the hands of the film-makers. When science consultants are involved, however, Grunig's definition of communication correlates with the expansive definition of Shapin and Schaffer's conception of virtual witnessing I have outlined earlier. It is in this sense that fictional films play a role in interspecialist communication. Science consultants are attempting to 'reconstruct' their interpretations of nature in the minds of the audience, both non-specialists and specialists alike. As I will show below, the fact that other scientists in the consultant's field respond to these 'reconstructions' of natural phenomenon is evidence that fictional films can serve as effective communication devices between specialists.

\section{Fictional Films as Modeling Spaces}

Films act as virtual witnessing technologies and inter-specialist communication vehicles, because film-makers are asking science consultants to help them develop models of the natural world. The use of films as modeling tools is quite common in scientific practice. In many cases, scientists use 'animated' films as simulation tools that allow them to theoretically model a system without having to set up an experiment or to 
examine a phenomenon without having to have actually seen it. For example, computer-generated animation models have long been routine equipment in seismology, molecular biology, and astronomy. ${ }^{23}$ In fact, Bruce Lewenstein and Steven Allison-Bunnell (2000) show that researchers from the Jet Propulsion Laboratory at Caltech were able to better visualize their data on Venus and Mars by being involved in the construction of an IMAX film. According to Lewenstein and Allison-Bunnell (2000: 202), 'the need of the IMAX film for dramatic moving images provided researchers with the funds and the opportunity to create new ways of viewing their scientific data, leading them to new appreciations of the complexity and richness of the two planets' ${ }^{24}$ It is in this vein that I consider fictional films a modeling tool that allows scientists to represent systems and phenomena with a very sophisticated visualizing technology. Because these modeling tools are used in a fictional context, however, science consultants feel unrestricted in designing models according to their own conceptions of nature. According to Stephen Hilgartner (1990), the scientific community views popularization as a 'simplification' process, and as such, they are more willing to discuss speculative interpretations than they could do in 'serious' scientific publications. As Massimiano Bucchi describes it:

The popular stage in this sense provide an open space where stimuli, ideas and information are merged and exchanged among different actors and across disciplinary fields, in the absence of the constraints and conventions which bind scientific work and communication at the specialist level. (1996: 386)

Many of the consultants on fictional films regard films as an open, 'free' space to put forward their conceptualizations. Marvin Minsky of the Massachusetts Institute of Technology, who consulted on 2001: A Space Odyssey (1969), considers science fiction as a good way to work out some theoretical problems. As Minsky says, 'I thought that science fiction was a good venue for exploring the implications of AI [artificial intelligence]. It helps you to be clearer about the implications of your work' (quoted in Stork, 1997a: 30). This freedom to 'explore' in fictional spaces means that science consultants are often modeling interpretations of nature that are controversial among scientists. It is in these cases where the phenomena to be modeled do not have consensus in the scientific community that fictional film plays a role in inter-specialist communication.

\section{Consultants' Control Over Fictional Representation}

In arguing for scientists' use of fictional films as 'tools', I do not wish to give the false impression that scientists have total control over the portrayal of scientific images to which they contribute. The role of a science consultant is to give advice and they must often defer to film-makers' decisions. According to Willy Ley, for example, Hermann Oberth constantly battled Fritz Lang about how to portray the moon in Woman in the Moon. Oberth was insistent that the moon lacked an atmosphere and that 
this would require that the characters be shown wearing spacesuits. Lang's response to Oberth emphasized his need to tell a compelling story: 'How could one present a love story taking place on the Moon and have the lead characters talk to each other and hold hands through space suits?' (Ley, 1943). As the director, Lang had final say over what appeared in the film and thus the airless Moon was presented as having an atmosphere. The famous scientific artist Chesley Bonestall faced similar problems on the film Conquest of Space (1955). His desire for a 'realistic' looking planet was thwarted by film-makers who wanted to show what they thought would be a 'realistic' looking Martian landscape:

I [Bonestall] also painted a big mural for Mars which they never used. Why? Because it looked too much like Arizona. And Dr. Richardson [from the Palomar Observatory in Los Angeles] told them, 'Well, you know, Mars looks a lot like Arizona.' But it wasn't acceptable. So you had to fight in the motion picture business. (quoted in Hickman, 1977)

As this example illustrates, when conflicts arise between consultants and film-makers it is the film-makers who make the ultimate decisions about what appears on the screen. The film-maker may feel that advice or suggestions from scientists interfere with the story or what the film-maker thinks audiences want to see.

Despite this, there is ample evidence that consultants have a great deal of control over the 'science' in a film. Hermann Oberth, for instance, may have lost battles over how to portray the moon, but Fritz Lang left depictions of the rocket launch entirely in Oberth's hands. Likewise, Fred Anderson (1995) demonstrated that 'authenticity' was a marketing tool for Hollywood studios' historical dramas, including Warner Brothers' scientist bio-pics such as The Story of Louis Pasteur and Dive Bomber (1941), for films of the $1930 \mathrm{~s}$ and $40 \mathrm{~s}^{25}$ According to medical historians Susan Lederer and John Parascandola (1998), this insistence on authenticity led Warner Brothers to rely heavily on science advisors, including biochemist Stanley Fox and two anonymous medical researchers (who felt that 'professional ethics' prohibited them from receiving any credit), while filming Dr. Ehrlich's Magic Bullet. Evidence from recent films, such as Dante's Peak (1996), Twister, Armageddon and Deep Impact, actually suggests an increase in science consultants' power on the set. For example, Phil Tippett, Furassic Park's special dinosaur effects supervisor, had a problem 'filming' Velociraptors (raptors). The difficulty was that a great deal of the raptor's screen time involved raptors standing around, which was cinematically boring. The special-effects artists wanted raptors to do something to 'fill the time with interesting action'. Tippett explains how he came up with a cinematically satisfactory solution and how paleontologist Jack Horner shot down this solution:

One of the things I [Tippett] came up with was a flicking tongue movement. We shot all the animatics that way and it was a great time filler - the tongue movement would really enliven a dead scene. But when Jack Horner - the paleontologist on the show - saw it, he said: 'What are you 
doing? Raptors didn't do that! They physically couldn't do that! This is terrible!' We all wanted to be as authentic with these things as possible, so we got rid of the tongue movement. (quoted in Shay \& Duncan, 1993)

The rise in science consultants' increased influence comes from filmmakers' increased desire for 'realism' as discussed earlier. Thus, Universal Pictures was willing to scrap an effect that certainly cost tens of thousands of dollars, 'enlivened' scenes involving raptors, and may have taken weeks to produce, because a paleontologist complained that it was not 'real'. Even if they are not behind the actual physical construction of images and scenarios, scientists come up with the conceptual ideas that become 'models' of nature on the screen. What is most important to remember is that while consulting on a film is not a guarantee that a scientist's conceptions of nature will get into the film, it increases the likelihood, since they are the first person a film-maker will turn to when they want advice about portraying science.

\section{Fictional Films as Speculative Spaces}

The use of film as a modeling space by science consultants is why many films in retrospect seem 'ahead of their time'. For example, film critics often point to Woman in the Moon as a 'prophetic' film (e.g. Jensen, 1969). Indeed, many of the scientific ideas used in the film have come to pass. NASA has used the mobile launch vehicle depicted in the film on every launch since Apollo, the Saturn rocket's booster design was identical to the one represented in the film, and NASA decided in 1981 to rest the Space Shuttle in a pool of water during take-off just as the rocket in the film was put in a pool of water to protect its 'delicate parts' (Freeman, 1993: 48). Willy Ley notes that because of ' $a$ dramatic requirement - the director [Fritz Lang] wanted a full moon in the sky during take-off - the flight path that Oberth calculated turned out to be the figure- 8 flight path actually taken by Apollo 8' (Ley, 1969: 29). This is not to say that NASA scientists calculated their trajectory for Apollo 8 based on Woman in the Moon. Rather, Oberth was speculating on a trajectory' as if he actually was planning a rocket trip to the moon, and other scientists later accepted his speculative trajectory as accurate. The film only seems prophetic because Oberth was using the film to model his ideas for what a moon flight should entail, ideas that he also promoted in venues other than the film, including technical publications. In many cases, scientists decided his ideas were a correct path for their own research or experiments. ${ }^{26}$

In fact, Oberth's 'models' for the film conveyed his ideas and theories so well that the Nazis considered the physical rocket models and the film a national security liability. In an oft-quoted story, the Germans were afraid that other scientists would acquire ideas about rocket technology from Woman in the Moon. The film's production company, UFA, donated the spaceship models to the VfR where future rocket scientists, including Wernher von Braun, studied Oberth's design. Many of Oberth's students, and other supporters of his theories, were at the forefront of German 
rocket design during the Second World War. Nazi authorities decided that the film's depiction of the development of a rocket propulsion system was too similar to experiments with the V-1 and V-2 rockets. The Nazis believed that the Allies' scientists would learn information about rocketry from the film, so the Gestapo destroyed the model spaceships and every print of the film they could find. Aware of Woman in the Moon, the British foreign office expressed concern that the film's 'realistic' depiction of rockets revealed German rocketry's highly advanced state.

Another way to think about the idea of fictional films as scientific modeling tools is to examine a more recent film where a science consultant has modeled phenomena that have yet to be verified by close visual inspection. Astrophysicist Jacklyn Green designed the surface of the 'rogue moon' in the gravity field of a 'blue giant' star for the film Supernova (2000). Currently, the structure and appearance of a small body near a high-gravity entity are an open question in the astronomical community; nobody has actually had close contact with such a body. Green, who runs the Extraterrestrial Materials Simulation Laboratory for the Jet Propulsion Laboratory (JPL), essentially designed the moon based on her theories concerning bodies in the vicinity of a high-gravity field. When, and if, we ever come into close contact and are able to confirm what such a body looks like, it may indeed appear like it did in the film or it may look completely different. Nevertheless, being a consultant on the film allowed Green the filmic space to develop, visualize, and experiment with her conceptual models.

\section{Scientific Responses to Fictional Film Representations}

The composition of small celestial bodies is highly contested, with many competing visions. ${ }^{27}$ Supernova, however, provided Green with a vehicle by which to communicate her own vision. Green is presenting an account of nature with the intent of convincing others, including other scientists, that this interpretation represents 'reality'. This reading of science consultants and fictional films as inter-specialist communication, however, requires that the consultants' representations have successfully been communicated to other scientists. Evidence that scientists have received these models comes from the fact that occasionally they will respond publicly to the models and images in the films. Most often these responses come in the form of 'The Real Science of' articles in which a scientist critiques the 'scientific accuracy' of a fictional film in a newspaper/magazine article or in 'cinematic science reviews' for research journals such as Nature or Science. Essentially when scientists critique scientific representations made with the assistance of a science consultant they are criticizing the consultant's conceptions of scientific 'facts' ${ }^{28}$ I will use the furassic Park film series to demonstrate how fictional films can serve as inter-specialist communication.

furassic Park and its two sequels, The Lost World and furassic Park III, feature aspects of dinosaur evolution and ecology that were not entirely 
accepted by the scientific community at the time of each film's release. Science consultant Jack Horner is a well-known proponent, and progenitor, of many of the controversial ideas in the film. For example, in furassic Park birds are represented as having evolved from a dinosaur ancestor rather than from another branch of reptiles. This theme actually plays a large role in the film and is portrayed in the film as the 'radical' hypothesis of fictional paleontologist Alan Grant, who is based on the real-life Jack Horner (Connor, 1993; Dawson, 1994; Gallagher, 1993). Throughout the course of the film the audience is presented with visual 'evidence' to support Grant's (i.e. Horner's) theories of a bird-dinosaur evolutionary relationship. When we first meet Grant, for instance, he explains to his field assistants, and of course to the film's audience, his notions of the birddinosaur relationship. He backs his explanation up by pointing to a computer screen that visualizes a complete Velociraptor fossil:

GRANT: Look at the half-moon shaped bones on the wrists. No wonder these guys learned how to fly. (The field assistants laugh at him.) Seriously. Well maybe dinosaurs had more in common with present day birds than they do with reptiles. (Pointing at the image of the Velociraptor fossil on the computer screen.) Look at the pubic bone turned backward, just like a bird. Look at the vertebrae full of air sacs and hollows just like a bird. And even the word raptor means 'bird of prey'.

With the guidance of Jack Horner, the film-makers create a computergenerated image of a 'Velociraptor fossil' that one of the main characters can use as a visual device to explain Horner's theories of bird evolution. There are several other scenes in the film that present the audience with the 'visual evidence' that birds evolved from dinosaurs. In a scene where a pack of Gallimimus run away from a $T$. rex, Grant exclaims that the Gallimimus move with 'uniform direction changes, just like a flock of birds evading a predator'. Of course, the audience sees this 'flocking' just as Grant does and Grant's dialogue encourages the audience to 'witness' his interpretation of these actions as well.

Other examples in the furassic Park series of concepts that can be attributed to Horner include the hypotheses that dinosaurs were warmblooded animals, that they had a communal nature, that Velociraptor used sophisticated communication, that $T$. rex nurtured its young, and that $T$. rex was exclusively a scavenger. None of these concepts have a complete consensus in the scientific community and many of them are the subjects of heated debates. However, in the case of the furassic Park films only one side of dinosaur 'science' got screen time. Scientists who disagree with these depictions have found other outlets to express their notions about 'true' representations of dinosaurs. For example, some of the scientists who visually and thematically 'lost out' have since put together a list reframing the 'science' in the first two furassic Park films. 'The Dinosaur Interplanetary Gazette' (1997) hosts the list and it is a collection of competing paleontologists' alternative beliefs about dinosaurs, labeling Spielberg and Horner's fictionalized science as 'science bloopers' ${ }^{29}$ Harvard University paleontologist Stephen Jay Gould (1993) also disagreed 
with many of the dinosaur depictions in Furassic Park (he referred to T. rex's posture as 'currently fashionable'), writing an article on the film for The New York Review of Books criticizing these depictions. Gould recognized that the disputed interpretations were not 'science bloopers' on the part of film-makers, but represented competing scientists' visions of dinosaur evolution and ecology. Referring to the dinosaur depictions as 'professional speculation' he says, 'As a practicing paleontologist, I confess to wry amusement at the roman-à-cleffery in the reconstructions. I could recognize nearly every provocative or outré idea of my colleagues' (Gould, 1993: 54). In other words, Gould is clearly able to see the controversial scientific ideas that went into the 'fictional' representations. Moreover, he not only disagrees with these ideas, he considers them outré or bizarre. As with the case of the 'blooper' list, Horner's version of 'accurate' dinosaur science becomes Gould's vision of 'bizarre' science.

The ability of film to act in inter-specialist communication does not even rely on the 'receiving' scientist's awareness that another scientist is responsible for the images and ideas on the screen. Scientists who responded to the film rarely attacked Jack Horner by name. They were, however, attacking his ideas and concepts of dinosaur science (e.g. warmblooded dinosaurs), presenting their own concepts as 'real science' and labeling Horner's interpretations as 'fiction'. In some instances scientists recognize that a science consultant has worked on the film and include this information in their responses. This situation has become more common as more and more films utilize science consultants. Moreover, the fact that scientists mention science consultants in their 'science film reviews' highlights filmic representation as a means of inter-specialist communication. Mission to Mars illustrates this point.

The plot of Mission to Mars revolves around the fictional first manned mission to Mars. Film-makers brought in physicist Robert Zubrin to help them design a 'plausible' plan for colonizing Mars. According to the film's 'Production Notes' Zubrin's proposal for a trip to Mars became a major focal point for the film-makers before production even started:

During the development phase of the film, a magazine article came to the producer's attention: an excerpt from Robert Zubrin's book, The Case For Mars. 'It was about going to Mars and it was fascinating, with a tremendous amount of technical detail', [producer Tom] Jacobson says ... Zubrin was hired as a consultant during development of the script and then Jacobson purchased the rights to his book. 'In this non-fiction work, there is so much detail about how we could go to Mars, including proposals for spaceships, Mars habitats and mission plans,' the producer says. 'Once we started pre production, we gave the book to practically everyone involved in the movie. It's very inspirational'. (Production Notes, 2000)

Given the space science community's familiarity with Zubrin's Mars colonization scheme, it is not surprising that other scientists saw Zubrin's hand in the making of the film. Sonoma State University astrophysicist Philip Plait (2000) was critical of Zubrin's Mars Direct plan in reviews of 
Zubrin's work before he saw the film, referring to elements of the plan as 'shaky'. ${ }^{30} \mathrm{He}$ notes that he was not surprised to learn that Zubrin acted as consultant on the film: "He is the author of the "Mars Direct" plan, which is basically a quick and easy way to get to Mars. His plan is controversial; many space experts think it won't work. I have serious doubts as well'. Although he still has doubts about Zubrin's ideas, Plait also claims that he is impressed by the plan as it is depicted in the film, calling it 'very clever, and a good idea'. He concludes, 'when we do it for real, it might be the working model of the actual method employed'. While reading Zubrin's work Plait had reservations, but when he saw the ideas portrayed in film the scheme became 'clever' and a 'good idea'.

Disney's Touchstone Pictures provided Zubrin the opportunity to 'show' people, including fellow colleagues, that his Mars Direct plan could work. Although Plait certainly is not a true convert to Zubrin's Mars Direct plan (he still expresses some doubts), Zubrin's filmic representation of the Mars mission appeared to Plait to be workable. Consultants' representations can yield either positive or negative reactions among scientists; regardless, scientists respond to these representations, indicating that fictional films play a role in inter-specialist science communication.

Even when a film, such as Deep Impact, receives a very warm reception by the scientific community, it still generates scientific critiques. Paramount Pictures contacted several scientific news outlets, such as Scientific American, Sky and Telescope and the Learning Channel, months in advance, to promote the film-makers' commitment to 'scientific accuracy' and to tout the involvement of several science consultants (Yam, 1998). Many scientific reviewers appreciated Paramount's attempts at scientific accuracy. It was not uncommon in the scientific reviews to find responses such as David Morrison's 'Terrific!' or JPL's Eleanor Helin's 'Zowie!' (Morrison quoted in Stanley, 1998; Helin quoted in Larson, 1998). University of Texas astronomer Peter Shelus's comments best sum up the response of scientists to the science in the film: 'Most of the scientists I know think it's a very reasonable movie scientifically' (quoted in Spotts, 1998).

Despite the claims of total 'scientific accuracy' by the studio, consultants argued among themselves as to what actually represented 'accurate' cometary science. According to an article in The Planetary Report, the consultants on Deep Impact disagreed about the texture of the comet's surface (Anderson, 1998). After the set designers finished the comet set, Eugene Shoemaker felt that the comet's surface looked too jagged, while Joshua Colwell felt that the surface had just the right amount of roughness. This means that the comet that appears on the screen matches Colwell's notions of a rough cometary surface, as opposed to the smoother surface that Eugene Shoemaker favored. It is Colwell's vision that gets communicated to other scientists through the film, not Shoemaker's. In this case most reviewers, like Kevin Zahnle (1998) of NASA's Ames Research Center, agreed with Colwell singling out the rough cometary surface as 'realistic'. The fact that only one of these scientists got their vision in the film highlights the fact that scientists have competing visions about what 
represents nature and, yet, only one, or a few, scientists have the opportunity to promote their vision as the 'truth' in filmic form.

As with most of the films in this study, reviewers aired their disagreements over the science in Deep Impact. Like Mission to Mars, scientists were aware that some of their colleagues consulted on the film and often referred to the consultants by name in their reviews. The use of nuclear weapons to divert the comet in the film spurred the most intense disagreements among reviewers. Some scientists agreed with the nuclear approach. David Morrison (1998), for example, felt that the strategy to deflect the comet with nuclear explosives was 'appropriate'. According to another reviewer, Mark Bailey of the Armagh Observatory, all other methods for diverting NEO are doomed to fail: 'Quite frankly, the only thing that is certain to work is nuclear power' (quoted in Byrne, 1998). In contrast, Stephen Maran (1998: H6) felt that the deployment of nuclear weapons in the film was flawed because 'most astronomers think that planting disruptive explosions for the purpose of collision avoidance is bad science'. Deep Impact even became the reference point in news accounts of Erik Asphaug's simulation experiments that came out in Nature just after the film's release. His study demonstrated that loosely packed comets would be unaffected by nuclear detonations (Asphaug et al., 1998).$^{31}$ Asphaug's study also caused him to give the film a 'thumbs up' for showing that the nuclear devices did not destroy the fictional comet (Spotts, 1998). Other reviewers offered alternative methods to diverting or destroying NEO, including chemical means, a laser shield, a single giant laser, and erecting a solar sail on the surface of the asteroid or comet.

One of the most interesting things about Deep Impact is that it clearly demonstrates how consultants and science reviewers can rely on different bodies of evidence and studies to construct their versions of science. For example, the scientific reviewers highly debated the behavior and make-up of debris near the comet. Before the film was released, The Planetary Report wrote an article in which three scientists reviewed the shooting script and provided their opinions about its science content (Anderson, 1998).$^{32}$ Then the journalist brought the reviewers' criticisms to the film's consultants. The reviewers questioned the 'accuracy' of the debris field surrounding the comet: 'All three [Planetary Report] reviewers raised their eyebrows at dialogue indicating that apartment-building-sized chunks menaced the spacecraft as it approached the comet. Common wisdom holds that a cometary nucleus is surrounded by gas and dust - meaning tiny bits of rock'. Consultant Chris Luchini defended his decision to advise on large fragments by citing studies done at JPL using radar observations of comet Hyakutake. According to Luchini, the inclusion of the large fragments in the debris field represented 'cutting-edge science' and he was 'very proud of getting it into the film'. The journalist followed up her discussion with Luchini by asking John Harmon of the Arecibo Observatory about the 'apartment-sized' fragments. According to Harmon, his work showed that the strength of the gas jets coming off Hyakutake were 
powerful enough that they 'could have blown off stuff tens of meters in size'.

What Luchini called 'cutting-edge science', other scientists, such as Iowa State University astronomer Mike Reed, found problematic. Reed believes existing evidence shows that 'most of the material that leaves a comet is smaller than the thickness of a single, human hair' (Reed, 1998). $\mathrm{He}$ also criticized the debris field on theoretical grounds: 'If the comet were losing mass (material) this quickly, we'd have nothing to worry about. It would be long gone before reaching the Earth' (Reed, 1998). Astronomer Randall Brooks (1998) also disagrees with the large fragments in the debris field and believes that evidence from other studies suggests smaller particles: 'The scenes of the rocky approach of the massive Orion spacecraft nearing the comet were, on the basis of spacecraft studies of comets like Halley's, overdone. Relatively few large rocks come off comets'. Although Luchini feels that recent studies support a debris field that can accommodate numerous large fragments, others, like Reed and Brooks, feel the evidence suggests otherwise. All these scientists are claiming to have the 'truth' based on different sets of evidence. Only Luchini, however, was able to communicate his beliefs through portrayal in a fictional film, thus propelling his ideas to the forefront of the audiences' minds.

\section{Conclusion}

A Time magazine article published in 2002 highlighted Kevin Pope's recent challenge to the theory that dust from an asteroid impact caused the extinction of the dinosaurs. Time's article contained a still from Dinosaur (2000) with the caption, 'Even Disney has accepted the asteroid theory' (Jaroff, 2002). The Disney film is acting as a cultural barometer to the acceptance or rejection of scientific thought. The Time article showcases the uphill battle Pope faces to get his scientific ideas on the map since 'even Disney' accepts the asteroid theory. Pope is not only fighting other scientists, but also representations, created with the help of scientists who accept the asteroid impact theory, in movies such as Deep Impact, Armageddon and Dinosaur. Pope, however, does not (yet) have access to a fictional film to publicize his ideas to millions of people. Realizing that 'even Disney' is treating the asteroid theory as 'black-boxed', Pope reached out to the public and other scientists through alternative communication routes: sending out a press release to promote his findings (LeBeau, 2002). The impact of fictional images on the debates over the dinosaurs' extinction highlights the need to move away from the 'scientific literacy model' for studying science in fiction and to incorporate the impact of fictional images on science itself as in the 'interactive science model'.

Fictional films play a role in the formation of consensus and closure in scientific controversies. The socially constructed nature of scientific knowledge means that scientists' knowledge claims only become 'facts' when consensus is reached. The consensus formation process is largely one of 
rhetoric and representational techniques of persuasion. To this end, scientists use multiple means to convince people of their claims' validity, including representations in fictional films. Film, in fact, can have a very powerful epistemological impact because of its virtual witnessing capacity. Film has the ability to create an image of the natural world on the screen and, thus, in the audience's mind; such images include 'here is what a comet looks like', 'here is how dinosaurs communicate', 'here is an effective cloning protocol', etc. When scientists design representations for films it is their conceptions of comets, dinosaurs, cloning protocols, etc., that make it onto the screen. The film, of course, does not imply uncertainty about any of these topics or suggest alternatives. The consultant's version is offered to viewers as realistic and natural within the fictional world system. Fictional films, in essence, force a consensus through the 'reality effect', even though this consensus is an illusion. Hollywood films produce a 'naturalizing' effect on their subject matter. Film-makers construct fictional films so that the film's content appears to be natural and normal. This is why film-makers hire consultants in the first place, to enhance this 'reality effect'. As I have shown, however, not every scientist agrees with the consultant's version of 'reality'.

As Table 1 shows, the number of scientists who consult on fictional media projects is steeply increasing as consulting becomes standard practice in the entertainment industry. Still, there are few scientists who serve as consultants on fictional films. This, however, makes it even more important to understand the role of fictional films in science communication and scientific practice. Those researchers who consult on fictional films have access to a very effective persuasive tool, one that few other scientists possess, that can disseminate their interpretations of natural phenomena to both the lay public and other scientists. Scholars of science studies have overlooked this contribution of fictional media to the creation

TABLE 1

Number of Films Utilizing Science Consultants by Decade and Percentage of Total Films

\begin{tabular}{lrr}
\hline Time period & \multicolumn{2}{c}{ Films } \\
& $n$ & $\%$ \\
\hline $1914-29$ & 7 & 6.9 \\
$1930-9$ & 10 & 9.9 \\
$1940-9$ & 8 & 7.9 \\
$1950-9$ & 11 & 10.9 \\
$1960-9$ & 7 & 6.9 \\
$1970-9$ & 11 & 10.9 \\
$1980-9$ & 11 & 10.9 \\
$1990-2001$ & 36 & 35.7 \\
Total & 101 & 100 \\
\hline
\end{tabular}

Notes: While all other time periods cover 10 years, the first time period (1914-29) covers 16 years and the last time period (1990-2001) covers 12 years 
of scientific knowledge. In this essay I have tried to bring the study of fictional media closer to the study of scientific practice by examining its role in science communication. The battleground over scientific ideas is not limited to scientific meetings and publications, or even to traditional popularizing realms such as documentaries and news articles. Any time a scientist discusses, or portrays, scientific information it is an act of persuasive communication, and as such it can have an impact on scientific practice.

\section{Notes}

A debt of gratitude is owed to my postdoctoral sponsor Bruce Lewenstein whose comments and criticisms were extremely helpful. I also owe a very special debt to Laura Gaither who read multiple versions of this paper and whose comments are reflected throughout this article. In addition, I benefited from suggestions I received from Mike Lynch and other members of Cornell University's Department of Science and Technology Studies. Insightful comments from Malcolm Ashmore and three anonymous reviewers helped to clarify several points, especially the discussion of virtual witnessing. The research for this paper was supported through a National Science Foundation Postdoctoral Fellowship (NSF 0136119).

1. For comprehensive reviews of the ways in which mass media communication impacts science see Einsiedel \& Thorne (1999) and Logan (2001). The following publications are a representative sample of work on the impact of mass media communication on scientific practice: Whitley (1985), Cloître \& Shinn (1985), Hilgartner (1990), Lievrouw (1990), Lewenstein (1995), Mitman (1999), Simon (2001), and Bucchi (1998).

2. Studies that examine entertainment media's impact on science include Collins (1987), LaFollette (1990), Mitman (1999), and Davies (2000). Although Gregg Mitman's book Reel Nature (1999) is mainly concerned with the construction of 'wildlife films' as entertainment pieces he does deal with several fictional Disney films. Scientific films themselves have come under recent study as well. For examples, see Haraway (1989) and Cartwright (1995).

3. This is not to say that researchers have not addressed questions on the presentation of science in fictional media. However, these studies are about science in media and not about media's impact on science. Over the last decade there have been numerous academic studies on the cultural influences on the portrayal of science in visual fictional media. Jon Turney (1998: 5) refers to these studies as a 'cultural history of images'. Some studies of note include Basella (1976), Reingold (1985), Shortland (1988), Weart (1988), Goldman (1989), Tudor (1989), Lambourne et al. (1990), Elena (1993), Nelkin \& Lindee (1995), Pernick (1996), McCurdy (1997), Skal (1998), and Vieth (2001). This list is not meant to be complete, but merely representative of the types of work that have incorporated visually based fiction. As with visually based entertainment media, studies of fictional literature and science eschew fiction's impact on science for a cultural studies based approach: Haynes (1994), Van Dijck (1998), and Lambourne (1999). One interesting exception is the work of Hugh Crawford, who examines how fictional works reflect Bruno Latour's actor-network theory. See Crawford (1997a, 1997b).

4. See, for example, Tudor (1974), Jowett \& Linton (1980), Chesbro (1984), Kuhn (1985), Jarvie (1987), Fiske (1989), Brummett (1994), and Black (2002).

5. For some representative analyses of representation in scientific practice see Lynch \& Woolgar (1990), Ruse \& Taylor (1991), Levine (1993), Henderson (1998), Trumbo (1999), and Beaulieu (2001).

6. As a communication system, film must impart meanings to the receiver of its message. Signification refers to the various media and technologies through which a film's 
meanings are produced. According to film theorist Graeme Turner (1993: 50), 'Film is not one discrete system of signification, as writing is. Film incorporates the separate technologies and discourses of the camera, lighting, editing, set design and sound - all contributing to meaning'.

7. A 'The Real Science of' analysis consists of a scientist, or scientists, critiquing a fictional text in terms of what they see as 'inaccurate' science. For example, astronomer Stephen Maran (1998) discusses the 'real science' as he sees it in the fictional films Armageddon (1998) and Deep Impact (1998).

8. The following film encyclopedias were used for plot summaries: the annual The Motion Picture Guide, the annual Screen World (1949-), American Film Institute Catalogs 1911-1920 (1989), 1921-1930 (1971), 1931-1940 (1994), 1941-1950 (1999), 1961-1970 (1997), The Internet Movie Database < www.imdb.com >, Warren (1982), Hardy (1984), Anderson (1985), Nash \& Ross (1985), and Kinnard (1995).

9. Film credits were examined in the films themselves and in the references in note 8 .

10. Studio promotional material was checked at The Library of Congress's Motion Picture and Television Reading Room in Washington, DC and the Margaret Herrick Library's Center for Motion Picture Study in Los Angeles.

11. For examples of the varying uses of virtual witnessing see Daston \& Galison (1992), Ezrahi (1995), Carey (1997), Fox (1997), Cunnigham (2001), and Draaisma \& de Rijcke (2001).

12. For good reviews of the debates over mammalian cloning protocols in the late $1970 \mathrm{~s}$ and early 1980s see Mclaren (1984), Sun \& Moor (1995), and Solter (2000).

13. See Sobchack (1987), Neale (1990), Stern (1990), Landon (1992), Allen (1995), Carroll (1996), Prince (1996a), Singer (1998), Baird (1998), Buckland (1999), Hallam (2000), and Black (2002).

14. While Carroll notes that film theorists accept the notion of film realism, the nature of filmic reality is highly contested among film theorists.

15. Prince's main argument is that digital imaging makes the distinction between realist and formalist film theory irrelevant: 'Digital imaging exposes the enduring dichotomy in film theory as a false boundary' (p. 34).

16. Prince summarizes the literature on correspondence theory and perceptual reality in Prince (1993, 1996b).

17. All subsequent quotes in this paragraph are from this source.

18. For science content in television see Gerbner et al. (1981) and Gerbner (1987). For science content in horror films see Tudor (1989).

19. In one case, Space Frontier Foundation president Rick Tumlinson actually approached Paramount Pictures (Deep Impact) and the Walt Disney Co. (Armageddon) requesting financial support (Kemp, 1998).

20. For example see the testimony of Clark R. Chapman of the Southwest Research Institute < http://impact.arc.nasa.gov/congress/1998_may/chapman.html > or Pat A. Dasch of the National Space Society < http://www.nss.org/news/mailings/ mailing 14.html > .

21. Woman in the Moon was released in the United States of America under the title Rocket to the Moon in 1931.

22. Derek Bousé (1998) convincingly argues that nature films do not fit within the genre of documentary and that they deserve their own genre label.

23. For example, see Service (1997), Asphaug (1997), Vale \& Milligan (2000), and Anonymous (2001a, 2001b).

24. A similar incident, involving production of new three-dimensional simulations of the universe for the 'Nova' TV show, was described by Nova's executive producer, Paula Apsell (2002).

25. Anderson points out that this authenticity only held for costumes, equipment, and settings and did not extend to the characters or chronology.

26. Rocket scientists did actually get at least one idea directly from the film: the countdown. In this case, however, the idea did not come from Oberth or the other scientists on the set, but from director Fritz Lang. According to Lang, he designed the 
countdown for dramatic reasons: 'It came from a dire necessity, when I shot the takeoff I said, "If I count 1, 2, 3, 4, 10, 50, 100, an audience doesn't know when it will go off; but if I count down - 10, 9, 8, 7, 6, 5, 4, 3, 2, 1, ZERO! - then they will know. Thus the countdown"' (quoted in Bogdanovich, 1997). The film conveyed the methodological utility of this idea so successfully that German rocket scientists adopted the countdown as a research procedure, and it has since become the standard protocol used internationally for rocket science (Ley, 1968: 259, n. 5).

27. In fact, NASA recently funded a mission called 'Deep Impact' to determine the composition of Comet $\mathrm{P} /$ Tempel 1 in an attempt to settle this dispute. The scientists in charge of the mission claim they came up with the mission name before the film came out (Roylance, 1999; Sherwin, 1999). It is interesting to note, however, that the goal of the mission, to send an explosive device into a comet, mirrors one of the plot elements of the fictional film.

28. Consultants are certainly not responsible for all the science in a film. Often, fellow scientists critique an area of the film beyond the consultant's control. For example, several scientists criticize Armageddon (1998) for its unlikely scenario that a massive comet would go undetected until 18 days before impact and the futility of trying to destroy the comet at that point (e.g. Zahnle, 1998). Consultant Ivan Bekey encouraged film-makers to rectify these problems: 'I tried to get them to make it smaller, and I tried to get them to give more time before interception. It was no go' (Goldman, 1998).

29. This confluence of media types fits Lewenstein's web model for science communication (Lewenstein, 1995).

30. This and all subsequent quotes in this paragraph come from Plait (2000).

31. For some representative news accounts of their research see Irwin (1998) and Bowman (1998).

32. All subsequent quotes in this paragraph are from Anderson (1998).

\section{References}

Allen (1995) R. Allen, Projecting Illusion: Film Spectatorship and the Impression of Reality (Cambridge: Cambridge University Press).

American Film Institute Catalogs 1911-1920 (1989) (Berkeley, CA: University of California Press).

American Film Institute Catalogs 1921-1930 (1971) (New York: Bowker).

American Film Institute Catalogs 1931-1940 (1994) (Berkeley, CA: University of California Press).

American Film Institute Catalogs 1941-1950 (1999) (Berkeley, CA: University of California Press).

American Film Institute Catalogs 1961-1970 (1997) (Berkeley, CA: University of California Press).

Anderson (1998) C. M. Anderson, 'Deep Impact: Filming a Cosmic Catastrophe', The Planetary Report 18/3 (May/June): 12-15.

Anderson (1985) C. W. Anderson, Science Fiction Films of the Seventies (Jefferson, NC: McFarland \& Company).

Anderson (1995) F. Anderson, 'The Warner Brothers Research Department: Putting History to Work in the Classic Studio Era', The Public Historian 17/1: 51-69.

Anonymous (1922a) Anonymous, 'Dinosaurs Cavort in Film for Doyle', New York Times (3 June): $1,4$.

Anonymous (1922b) Anonymous, 'His Dinosaur Film a Hoax, Says Doyle', New York Times (4 June): 18.

Anonymous (1931a) Anonymous, 'Robert Esnault-Peltrie Speaking to American Interplanetary Society About Trips to the Moon', New York Times (16 January): 7.

Anonymous (1931b) Anonymous, '2000 Ride Rocket to Moon in Museum', New York Times (28 January): 10. 
Anonymous (1998) Anonymous, 'At Least There Will be a Warning', The Denver Rocky Mountain News (18 July): 56A.

Anonymous (2001a) Anonymous, 'Seismic Film Fest', Science 291 (12 January): 215.

Anonymous (2001b) Anonymous, 'Down a Black Hole', Science 292 (29 June): 2403.

Apsell (2002) P. Apsell, 'Sex, Lies, and Science Television', talk presented at 'Communicating the Future: Best Practices for Communication of Science and Technology to the Public', National Institute of Standards and Technology (8 March).

Asphaug (1997) E. Asphaug, 'Enhanced: New Views of Asteroids', Science 278 (19 December): 2070-71.

Asphaug et al. (1998) E. Asphaug, S. J. Ostro, R. S. Hudson, D. J. Scheeres and W. Benz, 'Disruptive Impacts Into Small Asteroids', Nature 393: 437-39.

Baird (1998) R. Baird, 'Animalizing Jurassic Park's Dinosaurs: Blockbuster Schemata and Cross-Cultural Cognition in the Threat Scene', Cinema fournal 37/4: 82-103.

Banned from the Ranch (1996) Banned from the Ranch, 'Twister: Computer Graphics and On-Set Playback', < www.bftr.com/Pages/projects/twister.html > .

Barker \& Brooks (1998) M. Barker and K. Brooks, Knowing Audiences: Fudge Dredd, Its Friends, Fans and Foes (Luton: University of Luton Press).

Barker \& Brooks (1999) M. Barker and K. Brooks, 'Bleak Futures by Proxy', in M. Stokes \& R. Maltby (1999): 162-74.

Basella (1976) G. Basella, 'Pop Science: The Depiction of Science in Popular Culture', in G. Holton and W. A. Blanpied (1976): 261-78.

Beaulieu (2001) A. Beaulieu, 'Voxels in the Brain: Neuroscience, Informatics and Changing Notions of Objectivity', Social Studies of Science 31/5: 635-80.

Black (2002) J. Black, The Reality Effect: Film Culture and the Graphic Imperative (New York: Routledge).

Bogdanovich (1997) P. Bogdanovich, Who the Devil Made It (New York: Alfred A. Knopf).

Bordwell \& Carroll (1996) D. Bordwell and N. Carroll (eds), Post-Theory: Reconstructing Film Studies (Madison, WI: University of Wisconsin Press).

Bousé (1998) D. Bousé, ‘Are Wildlife Films Really “Nature Documentaries”?', Critical Studies in Mass Communication 15/2: 116-140.

Bowman (1998) L. Bowman, 'Smashing an Asteroid Harder Than in Movies', Chicago Sunday Times (7 June): 39.

Bradley (2001) D. Bradley, " "It's the Dilithium Crystals Captain!" Science on the Screen', HMS Beagle 110 (14 September): <news.bmn.com/hmsbeagle/110/notes/adapt > .

Bromhall (1975) J.D. Bromhall, 'Nuclear Transplantation in the Rabbit Egg', Nature 258 (25 December): 719-22.

Brooks (1998) H. Brooks, 'Scientist Gives Film Passing Grade', The Ottawa Citizen (8 May): G3.

Brown (2000) C. Brown, 'End of the World is (Almost) Nigh; It's Official - the Possibility of Asteroids Devastating the Earth is No Longer Confined to Hollywood ScienceFiction', The Independent (3 September): 3.

Brown (2001) D. Brown, 'Centre to Inform Public on Risk of Asteroid Hits', The Independent (20 August): 9.

Brummett (1994) B. Brummett, Rhetoric in Popular Culture (New York: St Martin's Press).

Bucchi (1996) M. Bucchi, 'When Scientists Turn to the Public: Alternative Routes in Science Communication', Public Understanding of Science 5/4: 375-94 at 380.

Bucchi (1998) M. Bucchi, Science and the Media: Alternative Routes in Science Communication (London: Routledge).

Buckland (1999) W. Buckland, 'Between Science Fact and Science Fiction: Spielberg's Digital Dinosaurs, Possible Worlds, and the New Aesthetic Realism', Screen 40/2: 177-92.

Bunders \& Whitley (1985) J. Bunders and R. Whitley, 'Popularisation Within the Sciences: The Purposes and Consequences of Inter-Specialist Communication', in Shinn \& Whitley (1985): 61-77.

Byrne (1998) G. Byrne, 'Are We Sitting Ducks in a Cosmic Shooting Gallery?', The Daily Telegraph (12 March): 8. 
Carey (1997) D. Carey, 'Compiling Nature's History: Travellers and Travel Narratives in the Early Royal Society', Annals of Science 54/3: 269-92.

Carroll (1996) N. Carroll, Theorizing the Moving Image (Cambridge: Cambridge University Press).

Cartwright (1995) L. Cartwright, Screening the Body: Tracing Medicine's Visual Culture (Minneapolis, MN: University of Minnesota Press).

Chandler (1998) D. L. Chandler, 'Defying the Laws of Nature?', The Boston Globe (6 Jul.): $\mathrm{C} 1$.

Chesbro (1984) J. W. Chesbro, 'The Media Reality: Epistemological Functions of Media in Cultural Systems', Critical Studies in Mass Communication 1/2: 111-30.

Cloître \& Shinn (1985) M. Cloître and T. Shinn, 'Expository Practice: Social, Cognitive and Epistemological Linkage', in T. Shinn \& R. Whitley (1985): 31-60.

Collins (1987) H. M. Collins, 'Certainty and the Public Understanding of Science: Science on Television', Social Studies of Science 17/4: 689-713.

Conklin (2000) M. Conklin, 'In the Pull of Mars', Chicago Tribune (16 March): C1, C4.

Connor (1993) S. Connor, 'Hollywood Summons for Fossil Hunter', The Independent (16 July): 3.

Crawford (1997a) T. H. Crawford, 'Screening Science: Pedagogy and Practice in William Dieterle's Film Biographies of Scientists', Common Knowledge 6/2: 52-68.

Crawford (1997b) T. H. Crawford, 'Networking the (Non) Human: Moby-Dick, Matthew Fontaine Maury, and Bruno Latour', Configurations 5/1: 1-21.

Cunnigham (2001) R. Cunnigham, 'Virtual Witnessing and the Role of the Reader in a New Natural Philosophy', Philosophy and Rhetoric 34/3: 207-24.

Daston \& Galison (1992) L. Daston and P. Galison, 'The Image of Objectivity', Representations 40/1 (Fall): 81-128.

Davidson (1999) K. Davidson, Carl Sagan: $A$ Life (New York: John Wiley \& Sons).

Davies (2000) G. Davies, 'Science, Observation and Entertainment: Competing Visions of Postwar British Natural History Television, 1946-1967', Ecumene 7/4: 432-60.

Dawson (1994) J. Dawson, “ "Jurassic Park” Inspiration Pays Visit to St. Paul', Star Tribune (23 July): B1.

Dennis (1989) M. A. Dennis, 'Graphic Understanding: Instruments and Interpretation in Robert Hooke's Micrographia', Science in Context 3/2: 309-64.

Dervin \& Voight (1980) B. Dervin and M. J. Voight (eds), Progress in Communication Studies, Vol. II (Norwood, NJ: Ablex).

Draaisma \& de Rijcke (2001) D. Draaisma and S. de Rijcke, 'The Graphic Strategy: The Uses and Functions of Illustrations in Wundt's Grundzüge', History of the Human Sciences 14/1: 1-24.

Einsiedel \& Thorne (1999) E. F. Einsiedel and B. Thorne, 'Public Responses to Uncertainty', in Friedman et al. (1999): 43-58.

Elena (1993) A. Elena, 'Exemplary Lives: Biographies of Scientists on the Screen', Public Understanding of Science 2/3: 205-23.

Ezrahi (1995) Y. Ezrahi, 'Technology and the Civil Epistemology of Democracy', in Feenberg \& Hannay (1995): 159-71.

Feenberg \& Hannay (1995) A. Feenberg and A. Hannay (eds), Technology and the Politics of Knowledge (Indianapolis: University of Indiana Press).

Fiske (1989) J. Fiske, Understanding Popular Culture (Boston, MA: Unwin Hyman).

Fox (1997) S. Fox, 'Situated Learning Theory Versus Traditional Cognitive Learning Theory: Why Management Education Should Not Ignore Management Learning', Systems Practice 10/6: 727-47.

Freeman (1993) M. Freeman, How We Got to the Moon: The Story of the German Space Pioneers (Washington, DC: 21 st Century Science Associates).

Friedman et al. (1999) M. Friedman, S. Dunwoody and C. L. Rogers (eds), Communicating Uncertainty: Media Coverage of New and Controversial Science (Mahwah, NJ: Lawrence Erlbaum).

Gallagher (1993) S. Gallagher, 'Maverick Dinosaur Expert Gets in his Digs in Montana', Los Angeles Times (21 November): A14. 
Gerbner (1987) G. Gerbner, 'Science on Television: How it Affects Public Conceptions', Issues in Science and Technology 3 (Spring): 109-15.

Gerbner et al. (1981) G. Gerbner, L. Gross, M. Morgan and N. Signorielli, 'Scientists on the TV Screen', Society 18/4 (May/June): 41-44.

Goldman (1998) S. J. Goldman, 'The Science of Hollywood', Sky and Telescope 95/6 (June): $28-31$.

Goldman (1989) S. L. Goldman, 'Images of Technology in Popular Films: Discussion and Filmography', Science, Technology and Human Values 14/3: 275-301.

Goldner \& Turner (1975) O. Goldner and G. E. Turner, The Making of King Kong (New York: Ballantine Books).

Gooding (1989) D. Gooding, " "Magnetic Curves" and the Magnetic Field: Experimentation and Representation in the History of a Theory', in Gooding et al. (1989): 183-223.

Gooding et al. (1989) D. Gooding, T. Pinch and S. Schaeffer (eds), The Uses of Experiment: Studies in the Natural Sciences (Cambridge: Cambridge University Press).

Gould (1993) S. J. Gould, 'Dinomania', New York Review of Books (12 August): 51-56.

Gregory \& Miller (1998) J. Gregory and S. Miller, Science in Public: Communication, Culture, and Credibility (New York: Plenum Trade).

Grunig (1980) J.E. Grunig, 'Communication of Scientific Information to Nonscientists', in Dervin \& Voight (1980): 167-214.

Hallam (2000) J. Hallam with M. Marshment, Realism and Popular Cinema (Manchester: Manchester University Press).

Haraway (1989) D. Haraway, Primate Visions: Gender, Race, and Nature in the World of Modern Science (New York: Routledge).

Hardy (1984) P. Hardy, Science Fiction: The Complete Film Sourcebook (New York: William Morrow and Co.).

Haynes (1994) R. Haynes, From Faust to Strangelove: Representations of the Scientist in Western Literature (Baltimore, MD: Johns Hopkins University Press).

Henderson (1998) K. Henderson, On-Line and On-Paper: Visual Representation, Visual Culture, and Computer Graphics in Design Engineering (Cambridge, MA: MIT Press).

Hickman (1977) G.M. Hickman, The Films of George Pal (London: Thomas Yoseloff, Ltd).

Hilgartner (1990) S. Hilgartner, 'The Dominant View of Popularization', Social Studies of Science 20/3: 519-39.

Holton \& Blanpied (1976) G. Holton and W.A. Blanpied (eds), Science and its Public (Dordecht: D. Reidel).

Irwin (1998) A. Irwin, 'Bombs Have Little Impact on Asteroids', The Daily Telegraph (4 June): 4.

Jaroff (2002) L. Jaroff, 'What Wiped Out the Dinosaurs?', Time (4 February): 13.

Jarvie (1987) I. Jarvie, Philosophy of the Film: Epistemology, Ontology, Aesthetics (New York: Routledge).

Jensen (1969) P. M. Jensen, The Cinema of Fritz Lang (New York: A. S. Barnes \& Co.).

Jowett \& Linton (1980) G. Jowett and J. Linton, Movies as Mass Communication (Beverly Hills, CA: Sage).

Kemp (1998) S. Kemp, 'Warning of Real Disaster', The Herald (17 July): 18.

Kinnard (1995) R. Kinnard, Horror in Silent Films (Jefferson, NC: McFarland).

Kirby (2000) D. Kirby, 'The New Eugenics in Cinema: Genetic Determinism and Gene Therapy in GATTACA', Science Fiction Studies 27/2 (July): 193-215.

Kuhn (1985) A. Kuhn, The Power of the Image (New York: Routledge).

Kuhn (1990) A. Kuhn (ed.), Alien Zone: Cultural Theory and Contemporary Science Fiction Cinema (New York: Vesro).

LaFollette (1990) M. C. LaFollette, Making Science Our Own: Public Images of Science 1910-1955 (Chicago, IL: University of Chicago Press).

Lambourne (1999) R. Lambourne, 'Science Fiction and the Communication of Science', in Scanlon et al. (1999): 146-57.

Lambourne et al. (1990) R. Lambourne, M. Shallis and M. Shortland, Close Encounters?: Science and Science Fiction (New York: Adam Hilger). 
Landon (1992) B. Landon, The Aesthetics of Ambivalence: Rethinking Science Fiction Film in the Age of Electronic (Re)Production (Westport, CT: Greenwood Press).

Larson (1998) G. C. Larson, 'The Observatory', Minneapolis Star Tribune (1 July): 22A.

Latour (1986) B. Latour, 'Visualization and Cognition: Thinking with Eyes and Hands', Knowledge and Society: Studies in the Sociology of Culture Past and Present 6: 19-68.

Latour (1987) B. Latour, Science in Action (Cambridge, MA: Harvard University Press).

Latour (1990) B. Latour, 'Drawing Things Together', in M. Lynch and S. Woolgar (eds), Representation in Scientific Practice (Cambridge, MA: MIT Press): 1-40.

Leake \& MacAskill (1999) J. Leake and M. MacAskill, 'On Guard Against Armageddon: Governments are Getting Serious About the Threat of Collisions with Asteroids', The Ottawa Citizen (29 November): A8.

LeBeau (2002) K. LeBeau, 'Press Release - The K-T Impact Extinctions: Dust Didn't Do It', Geological Society of America <www.spaceref.com/news/viewpr.html?pid =7210 > .

Lederer \& Parascandola (1998) S. E. Lederer and J. Parascandola, 'Screening Syphilis: Dr. Ehrlich's Magic Bullet Meets the Public Health Service', fournal of the History of Medicine 53/4 (October): 345-70.

Levine (1993) G. Levine (ed.), Realism and Representation: Essays on the Problem of Realism in Relation to Science, Literature, and Culture (Madison, WI: University of Wisconsin Press).

Lewenstein (1995) B. V. Lewenstein, 'From Fax to Facts: Communication in the Cold Fusion Saga', Social Studies of Science 25/3: 403-36.

Lewenstein (2001) B. V. Lewenstein, 'Science and Media', International Encyclopedia of Social and Behavioral Sciences (Oxford: Pergamon): 13654-57.

Lewenstein \& Allison-Bunnell (2000) B. Lewenstein and S. Allison-Bunnell, 'Creating Knowledge in Science Museums: Serving Both Public and Scientific Communities,' in Schiele \& Koster (2000): 185-203.

Ley (1943) W. Ley, 'The End of the Rocket Society', Astounding Science Fiction 31/6: 64-78.

Ley (1968) W. Ley, Rockets, Missiles, and Men in Space (New York: Viking Press).

Ley (1969) W. Ley, Events in Space (New York: David McKay Co.).

Lievrouw (1990) L. Lievrouw, 'Communication and the Social Representation of Scientific Knowledge', Critical Studies in Mass Communication 17/1 (March): 1-10.

Logan (2001) R.A. Logan, 'Science Mass Communication: Its Conceptual History', Science Communication 23/2: 135-163.

Lynch (1990) M. Lynch, 'The Externalized Retina: Selection and Mathematization in the Visual Documentation of Objects in the Life Sciences', in Lynch \& Woolgar (1990): 153-86.

Lynch \& Woolgar (1990) M. Lynch and S. Woolgar (eds), Representation in Scientific Practice (Cambridge, MA: MIT Press).

McCurdy (1997) H. E. McCurdy, Space and the American Imagination (Washington, DC: Smithsonian Press).

Mclaren (1984) A. Mclaren, 'Methods and Success of Nuclear Transplantation in Mammals', Nature 309: 671-72.

Maran (1998) S. Maran, 'Movie Myths vs Scientific Reality', Washington Post (12 August): H1, H6.

Mitman (1999) G. Mitman, Reel Nature: America's Romance with Wildlife on Film (Cambridge, MA: Harvard University Press).

Morrison (1998) D. Morrison, New Films: Deep Impact and Armageddon, NASA Ames Space Science Division News Archive (5 May): <impact.arc.nasa.gov/news/1998/may/ 05.html >.

Morus (1988) I. Morus, 'The Sociology of Sparks: An Episode in the History and Meaning of Electricity', Social Studies of Science 18/3 (1988): 387-417.

Nash \& Ross (1985) J. R. Nash and S. R. Ross, The Motion Picture Guide, 1927-1983 (Chicago, IL: Cinebooks).

Neale (1990) S. Neale, “'You've Got to be Fucking Kidding!” Knowledge, Belief and Judgment in Science Fiction', in Kuhn (1990): 160-68. 
Nelkin \& Lindee (1995) D. Nelkin and M. S. Lindee, The DNA Mystique: The Gene as Cultural Icon (New York: W. H. Freeman and Co.).

Olson \& Czerkas (1987) E. C. Olson and S. M. Czerkas (eds), Dinosaurs Past and Present (Los Angeles, CA: Los Angeles County Museum of Natural History).

Padian (1987) K. Padian, 'The Case of the Bat-Winged Pterosaur: Typological Taxonomy and the Influence of Pictorial Representation on Scientific Perception', in Olson \& Czerkas (1987): 65-81.

Pernick (1996) M. Pernick, The Black Stork: Eugenics and the Death of 'Defective' Babies in American Medicine and Motion Pictures Since 1915 (Oxford: Oxford University Press).

Plait (1997) P. Plait, 'Review of Contact', Philip Plait's Bad Astronomy: < www.badastronomy.com/bad/movies/contact.html > .

Plait (2000) P. Plait, 'Review of Mission to Mars', Philip Plait's Bad Astronomy: $<$ www.badastronomy.com/bad/movies/m2mintro.html > .

Prince (1993) S. Prince, 'The Discourse of Pictures: Iconicity and Film Studies', Film Quarterly 47/1 (Fall): 16-28.

Prince (1996a) S. Prince, 'True Lies: Perceptual Realism, Digital Images, and Film Theory', Film Quarterly 49/3: 27-37.

Prince (1996b) S. Prince, 'Psychoanalytic Film Theory and the Problem of the Missing Spectator', in Bordwell \& Carroll (1996): 71-86.

Production Notes (2000) Production Notes from Mission to Mars, Touchstone Pictures.

Reed (1998) M. Reed, 'NOF Review of Deep Impact': < www3.iitap.iastate.edu/ mreed/ movies/review6.html >.

Reingold (1985) N. Reingold, 'Metro-Goldwyn-Mayer Meets the Atom Bomb', in Shinn \& Whitley (1985): 229-45.

Roach (1995) M. Roach, 'Virus the Movie', Health 9/3 (May/June): 78-84 at 80.

Roylance (1999) F. D. Roylance, 'Md. Scientists Involved in 2 New Space Missions', Baltimore Sun (9 July): A4.

Ruse \& Taylor (1991) M. Ruse and P. Taylor (eds), 'Special Issue on Pictorial Representation in Biology', Biology and Philosophy 6: 125-294.

Sagan (1995) C. Sagan, The Demon-Haunted World (New York: Random House).

Scanlon et al. (1999) E. Scanlon, E. Whitelegg and S. Yates (eds), Communicating Science: Contexts and Channels (London: Routledge).

Schiele \& Koster (2000) B. Schiele and E. H. Koster (eds), Science Centers for This Century (St Foy, Quebec: Editions Multi Mondes).

Screen World (New York: Crown Publishers, 1949-).

Service (1997) R. F. Service, 'Molecular Movies: Fast-Action Flicks Draw Chemists' Rave Reviews', Science 276 (27 June): 1986-1987.

Shapin (1984) S. Shapin, 'Pump and Circumstance: Robert Boyle's Literary Technology', Social Studies of Science 14/4: 481-552.

Shapin (1988) S. Shapin, 'Following Scientists Around', Social Studies of Science 18/3 (August): 533-50.

Shapin \& Schaffer (1985) S. Shapin and S. Schaffer, Leviathan and the Air-Pump: Hobbes, Boyle, and the Experimental Life (Princeton, NJ: Princeton University Press).

Shapiro \& Chock (1999) M. A. Shapiro and T. M. Chock, 'Media Dependency and Perceived Reality of Fiction and News', Paper presented at the International Communication Association, San Francisco.

Shay \& Duncan (1993) D. Shay and J. Duncan, The Making of Furassic Park (London: Boxtree Limited).

Sherwin (1999) A. Sherwin, 'NASA Comet Mission Will Echo Sci-Fi Film', The Times (13 July): 13.

Shinn \& Whitley (1985) T. Shinn and R. Whitley (eds), Expository Science: Forms and Functions of Popularisation (Dordrecht: D. Reidel).

Shortland (1988) $M$. Shortland, 'Mad Scientists and Regular Guys: Images of the Expert in Hollywood Films of the 1950s', Proceedings of the Foint Meeting of the British Society for History of Science and the History of Science Society (Manchester, England, July): 291-98. 
Simon (2001) B. Simon, 'Public Science: Media Configuration and Closure in the Cold Fusion Controversy', Public Understanding of Science 10/4: 383-402.

Singer (1998) I. Singer, Reality Transformed: Film as Meaning and Technique (Cambridge, MA: MIT Press).

Skal (1998) D.J. Skal, Screams of Reason: Mad Science and Modern Culture (New York: W.W. Norton).

Sobchack (1987) V. Sobchack, Screening Space: The American Science Fiction Film (New Brunswick, NJ: Rutgers University Press).

Solter (2000) D. Solter, 'Mammalian Cloning: Advances and Limitations', Nature Reviews Genetics 11/3: 199-207.

Spotts (1998) P. N. Spotts, 'Astronomers Check the Movie', The Christian Science Monitor (4 June): B1.

Stanley (1998) D. Stanley, 'Earth Really Could be a Bull's-Eye for an Asteroid', St. Louis Post-Dispatch (22 May): E7.

Stern (1990) M. Stern, 'Making Culture into Nature', in Kuhn (1990): 66-72.

Stewart (1992) L. Stewart, The Rise of Public Science: Rhetoric, Technology, and Natural Philosophy in Newtonian Britain, 1660-1750 (Cambridge: Cambridge University Press).

Stokes \& Maltby (1999) M. Stokes and R. Maltby (eds), Identifying Hollywood Audiences: Cultural Identity and the Movies (New York: bfi Publishing).

Stork (1997a) D. G. Stork, 'Scientist on the Set: An Interview with Marvin Minsky', in Stork (1997b): 15-31.

Stork (1997b) D. G. Stork (ed.), Hal's Legacy: 2001's Computer as Dream and Reality (Cambridge, MA: MIT Press).

Sun \& Moor (1995) F. Z. Sun and R. M. Moor, 'Nuclear Transplantation in Mammalian Eggs and Embryos', Current Topics in Developmental Biology 30: 147-76.

The Dinosaur Interplanetary Gazette (1997) The Dinosaur Interplanetary Gazette, 'Jurassic Park 2: The Lost World Science Bloopers!', (26 May), <www.dinosaur.org/ jparticles.htm >.

The Motion Picture Guide (Chicago, IL: Cinebooks, 1985-).

Trumbo (1999) J. Trumbo, 'Visual Literacy and Science Communication', Science Communication 20/4: 409-25.

Tudor (1974) A. Tudor, Image and Influence (London: Allen \& Unwin).

Tudor (1989) A. Tudor, Monsters and Mad Scientists: A Cultural History of the Horror Movie (Oxford: Basil Blackwell).

Turner (1993) G. Turner, Film as Social Practice (London: Routledge).

Turney (1998) J. Turney, Frankenstein's Footsteps: Science, Genetics and Popular Culture (New Haven, CT: Yale University Press).

Twentieth Century Fox (1951) Twentieth Century Fox, 'Predicts Noted Expert', Publicity Feature for The Day the Earth Stood Still.

Vale \& Milligan (2000) R. D. Vale and R. A. Milligan, 'The Way Things Move: Looking Under the Hood of Molecular Motor Proteins', Science 288 (7 April): 88-95.

Van Dijck (1998) J. Van Dijck, Imagenation: Popular Images of Genetics (New York: New York University Press).

Vieth (2001) E. Vieth, Screening Science: Contexts, Texts and Science in Fifties Science Fiction Films (Lanham, MD: Scarecrow Press).

Warren (1982) B. Warren, Keep Watching the Skies!: American Science Fiction Movies of the Fifties (Jefferson, NC: McFarland).

Weart (1988) S. Weart, Nuclear Fear: $A$ History of Images (Cambridge, MA: Harvard University Press).

Whitley (1985) R. Whitley, 'Knowledge Producers and Knowledge Acquirers: Popularisation as a Relation Between Scientific Fields and Their Publics', in Shinn \& Whitley (1985): 3-28.

Yam (1998) P. Yam, 'Making a Deep Impact', Scientific American 278/5 (May): 22, 24.

Yam (2000) P. Yam, 'Invaders from Hollywood', Scientific American 282/3: 62-63.

Zahnle (1998) K. Zahnle, 'Rocky Horror Picture Shows', Nature 394 (30 July): 435. 
David A. Kirby has a PhD in evolutionary genetics with publications in the Proceedings of the National Academy of Sciences and Genetics. Public Understanding of Science, Science Fiction Studies and Paradox have published his research on science communication and fiction. He is currently an NSF Postdoctoral Fellow in Cornell University's Department of Science and Technology Studies and will be moving to Duke University as a Mellon Postdoctoral Fellow in the Fall of 2003.

Address: Department of Science and Technology Studies, 306 Rockefeller Hall, Cornell University, Ithaca, New York 14853, USA; fax: +1 6072556044 ; email: dk246@cornell.edu 